\title{
Systematic Review \\ Benefits of Pilates in the Elderly Population: A Systematic Review and Meta-Analysis
}

\author{
Mário José Pereira ${ }^{1, *(D)}$, Rodrigo Mendes ${ }^{2}$, Rui Sousa Mendes ${ }^{2,3,4}{ }^{(D)}$, Fernando Martins ${ }^{2,3,5}$ (D), \\ Ricardo Gomes ${ }^{2,3,4}$ D , José Gama ${ }^{4}$, Gonçalo Dias ${ }^{2,3,4}$ (D) and Maria António Castro ${ }^{3,6,7}$ (D)
}

Citation: Pereira, M.J.; Mendes, R.; Mendes, R.S.; Martins, F.; Gomes, R.; Gama, J.; Dias, G.; Castro, M.A. Benefits of Pilates in the Elderly Population: A Systematic Review and Meta-Analysis. Eur. J. Investig. Health Psychol. Educ. 2022, 12, 236-268. https://doi.org/10.3390/ ejihpe12030018

Academic Editors: José Carmelo Adsuar Sala and Ana Belén Barragán Martín

Received: 28 December 2021 Accepted: 16 February 2022 Published: 22 February 2022

Publisher's Note: MDPI stays neutral with regard to jurisdictional claims in published maps and institutional affiliations.

Copyright: () 2022 by the authors Licensee MDPI, Basel, Switzerland. This article is an open access article distributed under the terms and conditions of the Creative Commons Attribution (CC BY) license (https:// creativecommons.org/licenses/by/ $4.0 /)$.
1 Faculdade de Ciências do Desporto e Educação Física, Universidade de Coimbra, 3040-248 Coimbra, Portugal 2 ESEC-UNICID-ASSERT, Instituto Politécnico de Coimbra, 3030-329 Coimbra, Portugal; a2019129465@esec.pt (R.M.); rmendes@esec.pt (R.S.M.) fmlmartins@esec.pt (F.M.); rimgomes@esec.pt (R.G.); goncalodias@fcdef.uc.pt (G.D.)

3 ROBOCORP, IIA, Instituto Politécnico de Coimbra, 3030-329 Coimbra, Portugal; maria.castro@ipleiria.pt

4 Research Unit for Sport and Physical Activity (CIDAF) (UID/DTP/04213/2020), Universidade de Coimbra, 3040-248 Coimbra, Portugal; jgama@esec.pt

5 Instituto de Telecomunicações (IT), 6201-001 Covilhã, Portugal

6 CEMMPRE (UIDB/00285/2020), Universidade de Coimbra, 3030-788 Coimbra, Portugal

7 Escola Superior de Saúde, Instituto Politécnico de Leiria, 2411-901 Leiria, Portugal

* Correspondence: mario.pereira@student.fcdef.uc.pt; Tel.: +35-191-846-6976
Abstract: The aim of this systematic review is to collect and summarize the benefits of Pilates in the elderly population ( $>60$ years old), within the current scientific production, assessing its contribution to Healthy Ageing (HA). We used PRISMA (Preferred Reporting Items for Systematic Reviews and Meta-analysis) to select, collect, and analyse this thematic. The methodological procedures were registered in the PROSPERO database. The main results of the studies analysed $(n=30)$ point to significant differences between the intervention and the control groups in dynamic balance, strength, mobility, functional capacity, risk of falling reduction, and mental and psychological health. Thus, the results showed that Pilates may be beneficial for the health of the elderly. The meta-analysis found statistical differences between means on the dynamic balance (mean difference (MD) $=-0.0$, $\left.95 \% \mathrm{CI}[-0.71,-0.50] ; I^{2}: 0 \%\right)$ and the aerobic capacity and aerobic resistance $[(\mathrm{MD})=38.29,95 \%$ CI $\left.[6.82,69.77] ; I^{2}: 0 \%\right)$. Thus, it is concluded that the efficacy of Pilates has been shown in various areas of HA and has proven to be affordable and safe for the majority of people, using just a mat on the floor. Future studies should focus on the analysis of the relationship between the cost and the benefit of a Pilates intervention in the elderly population, to better understand how health costs can be minimized and to contribute to a multidisciplinary and generalized HA. Pilates has practical application for the clinicians, therapists, and health professionals that work with the elderly population.

Keywords: elderly; health; active aging; balance; Pilates

\section{Introduction}

The number of people aged 80 years or more will triple and reach 434 million by 2050 . On a world scale, the number of people aged over 60 is increasing at a yearly rate of $3 \%$, far higher than the younger age groups. The prediction is that in 2050 the elderly will represent $22 \%$ of the population [1]. This demographic evolution has a strong social, political, and economic impact and is an indicator of the social transformation of the 21st century.

Ageing results in molecular and cellular decline, with a progressive influence on all body systems and, inherently, on the person's psychosocial condition [2,3]. Physical activity may help reduce the speed of this decline, raising or maintaining the elder person's intrinsic and functional capacity by improving physical capacities (e.g., strength, balance, and flexibility) [4]. Therefore, physical activity represents one of the factors that may 
minimize the direct influence of chronological age on the loss of bio-psychosocial function associated with ageing [5]. This multidisciplinary approach to ageing converges with the benefits of physical activity, given the pertinence and reach of its influence in the quality of life of the elderly [6]. Additionally, its efficiency and impact on the health of populations and the costs associated with these services fulfill the demands of current and future political decisions [1].

The Pilates method was developed in the 1920s by Joseph Pilates. Given its holistic approach, it is presented as one of the most efficient ways to reach the goals of Healthy Ageing (HA). It uses exercises that encompass a dualism — body and mind — which demands trunk stability, strength, and flexibility, as well as a focus on muscular control, body posture, and breathing. It uses six fundamental principles: (i) center, (ii) concentration, (iii) control, (iv) precision, (v) fluidity, and (vi) breathing. It may be done solo or in groups, with apparatuses (e.g., the Reformer or Trapezius) or on the ground (using a mat) or with only the body weight [7]. The efficiency of the Pilates method emerges from here, enabling psychomotor benefits and contributing to a better functional capacity, increasing independence and quality of life [8,9].

There has been a gradual increase in studies about the Pilates method in recent years [10]. The current research points to the efficiency of Pilates in health, particularly in physiotherapy and rehabilitation [11,12]. Additionally, there are psychological benefits [13,14] as well as benefits to the elderly person's quality of life $[15,16]$. Furthermore, there is an evident economic benefit when compared with other medical procedures and the absence of relevant contraindications. However, despite this evolution only three systematic reviews analyzing the benefits of Pilates interventions for the elderly were conducted in the last 5 years.

Thus, it seems pertinent to update the question: is Pilates an effective way to promote HA? If so, how? The aim of this systematic review and meta-analysis is to collect and synthesize the benefits of Pilates in the elderly population (older than 60), assessing its contribution to HA. This review included comparative studies, where Pilates was compared with other interventions, and studies with a control group without intervention. The results of physical capacities, such as strength, flexibility, and balance, as well as psychological and well-being variables, were analysed.

\section{Materials and Methods}

\subsection{Search Strategy}

This systematic review used PRISMA (Preferred Reporting Items for Systematic Reviews and Meta-analysis) [17] to select, collect, and analyse this thematic (Figure 1). The methodological procedures were registered in the PROSPERO database under the ID number CRD42021246371. Five databases were analysed: SportDiscus with Full Text; PEDro; PUBMED; Web of Science-Core Collection; and B-ON. The term "Pilates", associated with the descriptors "elderly" or "ag*" or "old* adult" and "health" or "physical fitness" or "functional capacity", and the Boolean operators "AND" and "OR", were used. The timespan selection is from 2016, and it is justified with the increase in the number of published studies in this field of study, from this date, and the need to systematize and update the knowledge during this period. Afterwards, the main crossed references of the articles included in the review were analysed. No grey literature research was made, and no specialists were consulted as no valid references were found. 


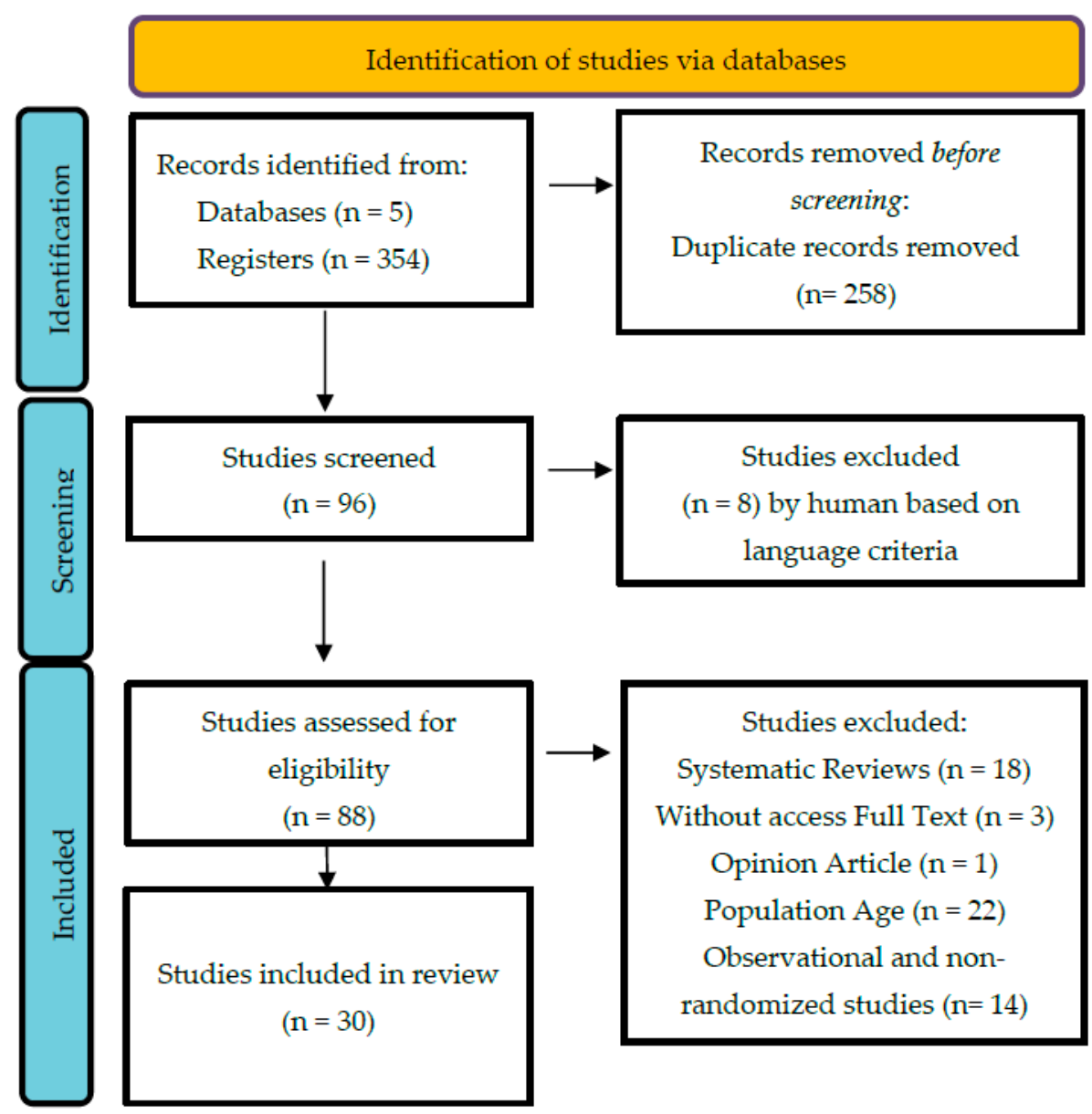

Figure 1. Prisma Flowchart (adapted from [18]).

\subsection{Eligibility Criteria}

The inclusion criteria were the following: (i) published works between 1 January 2016 and 21 April 2021; (ii) works written in English, Portuguese, Spanish, or French; (iii) studies that used the work "Pilates" in the title or in the keywords, with a sample over 60 years of age; (iv) random clinical trials; and (v) studies where Pilates was one of the dependent variables in the experiment. The following criteria were used for exclusion: (i) publications prior to 2016; (ii) publications without full text; (iii) academic theses, books, or non-scientific articles; and (iv) studies where the Pilates method was used along with other interventions or techniques (see Figure 1).

The selection process was conducted according to the following stages: (i) research that used the descriptors in the aforementioned databases; (ii) exclusion of duplicate articles; (iii) reading of abstracts; and (iv) critical reading and assessment of the articles (cf. Figure 1). The selection and extraction of the data from the articles was conducted in two stages. Firstly, two authors (MP, RM) made an independent selection and data collection from the eligible articles. After gathering both selections, the resolution of tie situations was solved in a meeting between both authors. If needed, a third author was called to decide (MC). After this process and the reaching of a consensus higher than $85 \%$, one of the authors (MP) completed the process for the remaining eligible articles. For a review of this nature, the most reliable source is the Random Clinical Experimental Trials (RCTs) [19]. Regardless, evidence from observational or non-randomized trials was equally included, broadening the span of the collection that could guide the intervention of the technicians using the Pilates methods in HA. To keep data quality control and the methodological requisites for this review, we chose to analyse and treat these two categories separately. Finally, the definition of an exclusion criteria of articles written in other idioms is justified by two 
reasons: the first is due to the fact the difficulty in assessing articles without consulting the full text would skew the data that would result from non-technical translations. The second is due to the fact that this idiom limitation has not changed the conclusions of the systematic reviews made [20].

\subsection{Quality Assessement}

PEDro (Physiotherapy Evidence Database) was used by two authors (M.J.P., R.M.) to independently register the included studies. The PEDro scale can be used in the assessment of the publication bias of the clinical trials [21]. It assesses two aspects of the quality of a clinical trial: (i) credibility, that is, internal validity and (ii) whether the article contains enough statistical information to be interpreted. The first item of the scale assesses the external validity and does not encompass the quantification of the final score. To assess the internal validity, eight criteria were used: (i) random distribution, (ii) secret allocation, (iii) comparison of groups in the beginning, (iv) blind subject, (v) therapist, (vi) evaluators, (vii) analysis by treatment intention, and (viii) complete following period (items 2-9 of the PEDro scale). To assess interpretability, statistical comparisons between the groups were used and, as reported, the (x) precision measurements and the (XI) variability (items 10 and 11 of the PEDro scale). The final score higher than 7 is attributed to a study with "high quality". Between 5 and 6, "moderate quality" is considered. Scores lower than 4 are of "low quality".

\subsection{Statistical Analysis}

This meta-analysis was conducted using the mean and standard deviation of the following variables: static balance, dynamic balance, balance confidence, strength and aerobic capacity, and resistance. All the data were analysed with Review Manager (RevMan, Version 5.4, the Cochrane collaboration, 2020). The data were grouped by random effects, with a confidence interval of 95\% (MD95\%). Heterogeneity was assessed with an I-squared test. In the case that this value was above $50 \%$, it would be classified as high, and the data would be relativized in the subsequent analysis. No publication bias study was conducted as we did not find more than 10 studies for any specific physical capacity [20].

\section{Results}

Of the five databases analysed, a total of 354 entries were considered eligible, according to the following distribution: SportDiscus $(n=31)$, PEDro $(n=21)$, PUBMED $(n=68)$, Web of Science Core Collection $(n=68)$, and B-ON $(n=166)$.

For this systematic review, 30 RCT studies were analysed. The remaining ones were non-randomized, and observational studies were included in the qualitative analysis in order to frame the practice and use of Pilates as a means of enhancing HA.

\subsection{RCT Studies}

The PEDro Scale assessment of the 30 studies resulted in 9 of low methodological quality, 14 of moderate quality, and 7 high-quality studies.

Tables 1-5 present the details of the studies analysed in this systematic review. 
Table 1. Structured summary of the studies included in the analysis (RCT).

\begin{tabular}{|c|c|c|c|c|c|c|c|c|c|}
\hline$n$ & Author & Title & $\begin{array}{l}\text { Subjects/ } \\
\text { Group }\end{array}$ & Objective & Intervention & Outcomes & Results & Conclusion(s) & $\begin{array}{l}\text { PEDro } \\
\text { Scale }\end{array}$ \\
\hline 1 & $\begin{array}{l}\text { Donath, L.; Roth, } \\
\text { R.; Hürlimann, C.; } \\
\text { Zahner, L.; Faude, } \\
\text { O. (2016) [22] }\end{array}$ & $\begin{array}{l}\text { Pilates vs. Balance } \\
\text { Training in Health } \\
\text { Community- } \\
\text { Dwelling Seniors: } \\
\text { a 3-arm, } \\
\text { Randomized } \\
\text { Controlled Trial }\end{array}$ & $\begin{array}{l}48 \\
\text { Pil } 16 \\
\text { BAL } 16 \\
\text { C } 16 \\
\text { M/F }\end{array}$ & $\begin{array}{l}\text { Examine the } \\
\text { effects of } \\
\text { traditional balance } \\
\text { training methods } \\
\text { vs. Pilates-based } \\
\text { training in balance } \\
\text { and trunk } \\
\text { strength. }\end{array}$ & $\begin{array}{l}\text { PIL: } \\
\text { Mat Pilates } \\
\text { BAL: } \\
\text { Traditional } \\
\text { balance training } \\
\text { C: } \\
\text { No intervention } \\
\text { Duration: } \\
8 \text { weeks } \\
\text { 2x week } \\
66^{\prime}\end{array}$ & $\begin{array}{l}\text { Freiburg Questionnaire } \\
\text { Static Balance } \\
\text { Dynamic Balance } \\
\text { Perturbing Kneeling } \\
\text { Trunk Strength }\end{array}$ & $\begin{array}{l}\text { Substantial positive } \\
\text { effects in favor of BAL compared to } C \\
\text { were } \\
\text { found for the } Y \text { balance score (right leg, } \\
\text { effect size }(d=0.68 \text {; left leg, } d=0.56 \text {, } \\
\text { trunk extension } \\
(d=0.68 \text { and single leg stance right leg, } \\
(d=0.61 ; \text { left leg, }(d=0.38 \text {. Dynamic } \\
(d=0.32 \text { and isometric } \\
(d=0.15 \text { trunk flexion revealed unclear } \\
\text { effects. } \\
\text { For the Y-balance score right leg, } \\
(d=0.48, \text { left leg, } d=0.75 \text { and single } \\
\text { leg stance right leg, }(d=0.61 ; \\
\text { left leg, } d=0.67, \text { interestingly, BAL } \\
\text { substantially } \\
\text { exceeded PIL. PIL vs. CON revealed } \\
\text { unclear effects } \\
\text { for most parameters }(0.05<d<0.36) \text {. }\end{array}$ & $\begin{array}{l}\text { Mat-based Pilates } \\
\text { training did not cause } \\
\text { relevant adaptations in } \\
\text { trunk strength and } \\
\text { balance performance, } \\
\text { whereas balance } \\
\text { training substantially } \\
\text { improved } \\
\text { balance and trunk } \\
\text { strength. }\end{array}$ & $4 / 10$ \\
\hline 2 & $\begin{array}{l}\text { Oliveira, L.C.; } \\
\text { Oliveira, R.G.; } \\
\text { Pires-Oliveira, } \\
\text { D.A. (2016) [23] }\end{array}$ & $\begin{array}{l}\text { Comparison } \\
\text { between static } \\
\text { stretching and } \\
\text { Pilates method on } \\
\text { the flexibility of } \\
\text { older women }\end{array}$ & $\begin{array}{l}32 \\
16+16 \\
F\end{array}$ & $\begin{array}{l}\text { To compare the } \\
\text { effects of static } \\
\text { stretching and } \\
\text { Pilates on the } \\
\text { flexibility of } \\
\text { healthy } \\
\text { older women, } \\
\text { over the age of } 60 \\
\text { years }\end{array}$ & $\begin{array}{l}\text { Pilates: } \\
\text { Static Stretching: } \\
\text { Duration: } \\
12 \text { weeks } \\
2 x \text { week } \\
60^{\prime}\end{array}$ & $\begin{array}{l}\text { Movements of the trunk } \\
\text { (flexion and extension), hip } \\
\text { flexion, and plantar and } \\
\text { dorsiflexion of } \\
\text { the ankle were performed } \\
\text { before and after the } \\
\text { intervention, using a } \\
\text { fleximeter }\end{array}$ & $\begin{array}{l}\text { The static stretching exercises } \\
\text { improved the trunk flexion and hip } \\
\text { flexion movements, while the Pilates } \\
\text { improved all evaluated movements. } \\
\text { However, over time, the groups } \\
\text { presented differences only for the trunk } \\
\text { extension movement }\end{array}$ & $\begin{array}{l}\text { For some body } \\
\text { segments, Pilates may } \\
\text { be more effective for } \\
\text { improving flexibility } \\
\text { in } \\
\text { older women } \\
\text { compared to static } \\
\text { stretching }\end{array}$ & $7 / 10$ \\
\hline 3 & $\begin{array}{l}\text { Oliveira, L.C.; } \\
\text { Pires-Oliveira, } \\
\text { D.A.; Prado, R.A.; } \\
\text { Oliveira, D.D.; } \\
\text { Antônio, T.; } \\
\text { Oliveira, R.F.; } \\
\text { Oliveira, R.G. } \\
\text { (2016) [24] }\end{array}$ & $\begin{array}{l}\text { Effects of Pilates } \\
\text { on postural } \\
\text { balance and } \\
\text { functional } \\
\text { autonomy of the } \\
\text { elderly: a } \\
\text { randomized } \\
\text { controlled trial }\end{array}$ & $\begin{array}{l}24 \\
\text { PA } 12 \\
\text { C } 12 \\
M / F\end{array}$ & $\begin{array}{l}\text { To verify the } \\
\text { effects of the } \\
\text { Pilates method, } \\
\text { based on the } \\
\text { functional } \\
\text { autonomy and } \\
\text { postural balance } \\
\text { in elderly women. }\end{array}$ & $\begin{array}{l}\text { PA: } \\
\text { Pilates apparatus } \\
\text { SS: } \\
\text { Static Stretching } \\
\text { Duration: } \\
\text { 8 weeks } \\
\text { 2x week } \\
60^{\prime}\end{array}$ & $\begin{array}{l}\text { Battery of tests for } \\
\text { functional autonomy of } \\
\text { the elderly, the Group of } \\
\text { Latin-American } \\
\text { Development to the } \\
\text { Maturity } \\
\text { (GDLAM) protocol, } \\
\text { six-minute walk test and } \\
\text { static postural balance on a } \\
\text { force platform. }\end{array}$ & $\begin{array}{l}\text { The results showed significant results } \\
\text { for GE in two tests of functional } \\
\text { autonomy and the overall rate of } \\
\text { functional autonomy }(p<0.05) \text {. } \\
\text { Differences for the other tests were not } \\
\text { found }\end{array}$ & $\begin{array}{l}\text { The intervention } \\
\text { protocol with Pilates, } \\
\text { allowed the } \\
\text { improvement of } \\
\text { functional autonomy } \\
\text { in elderly women, not } \\
\text { having an effect on the } \\
\text { six-minute walk test } \\
\text { and the postural } \\
\text { balance. }\end{array}$ & $4 / 10$ \\
\hline
\end{tabular}


Table 1. Cont.

\begin{tabular}{|c|c|c|c|c|c|c|c|c|c|}
\hline$n$ & Author & Title & $\begin{array}{l}\text { Subjects/ } \\
\text { Group }\end{array}$ & Objective & Intervention & Outcomes & Results & Conclusion(s) & $\begin{array}{l}\text { PEDro } \\
\text { Scale }\end{array}$ \\
\hline 4 & $\begin{array}{l}\text { Ángeles, M.V.; } \\
\text { Jiménez, J.M.; } \\
\text { Sánchez, J.G.; } \\
\text { Juan, F.R. (2016) } \\
\text { [25] }\end{array}$ & $\begin{array}{l}\text { Effects of a } \\
\text { Pilates-based } \\
\text { exercise program } \\
\text { on mood states in } \\
\text { older adults in } \\
\text { Mexico }\end{array}$ & $\begin{array}{l}20 \\
\text { MP } 10 \\
\text { C } 10 \\
\text { M/F }\end{array}$ & $\begin{array}{l}\text { Determine the } \\
\text { effect of a } \\
\text { Pilates-based } \\
\text { conditioning } \\
\text { program on the } \\
\text { mood of the } \\
\text { elderly. }\end{array}$ & $\begin{array}{l}\text { MP: Pilates Mat } \\
\text { C: No intervention } \\
\text { Duration: } 12 \\
\text { weeks } \\
3 x \text { week } \\
50^{\prime}\end{array}$ & $\begin{array}{l}\text { Profile of Mood States } \\
\text { (POMS) }\end{array}$ & $\begin{array}{l}\text { Significative differences in pre- and } \\
\text { post- measurements and between } \\
\text { groups for Tension }(p=0.001) \text {, Fury } \\
(p=0.030) \text {, Fatigue }(p=0.002) \text { and total } \\
\text { result }(p<0.0001) \text {. }\end{array}$ & $\begin{array}{l}\text { Pilates improves some } \\
\text { mood variables that } \\
\text { may influence the } \\
\text { emotional health of } \\
\text { the elderly. }\end{array}$ & $4 / 10$ \\
\hline 5 & $\begin{array}{l}\text { Barker, A.L.; } \\
\text { Talevski, J.; } \\
\text { Bohensky, M.A.; } \\
\text { Brand, C.A.; } \\
\text { Cameron, P.A.; } \\
\text { Morello, R.T. } \\
\text { (2016) [26] }\end{array}$ & $\begin{array}{l}\text { Feasibility of } \\
\text { Pilates exercise } \\
\text { to decrease falls } \\
\text { risk: a pilot } \\
\text { randomized } \\
\text { controlled trial } \\
\text { in community- } \\
\text { dwelling older } \\
\text { people }\end{array}$ & $\begin{array}{l}43 \\
\text { PA } 18 \\
\text { C } 25 \\
\text { M/F }\end{array}$ & $\begin{array}{l}\text { To evaluate the } \\
\text { feasibility of } \\
\text { Pilates exercise in } \\
\text { older people to } \\
\text { decrease falls risk } \\
\text { and inform } \\
\text { a larger trial. }\end{array}$ & $\begin{array}{l}\text { PA: } \\
\text { Pilates equipment } \\
\text { C: } \\
\text { Normal care } \\
\text { Duration: } \\
12 \text { weeks } \\
2 x \text { week } \\
60^{\prime}\end{array}$ & $\begin{array}{l}\text { Indicators of feasibility } \\
\text { including: acceptability } \\
\text { (recruitment, retention, } \\
\text { intervention adherence } \\
\text { and participant experience } \\
\text { survey); safety (adverse } \\
\text { events); and potential } \\
\text { effectiveness (fall, fall } \\
\text { injury and injurious fall } \\
\text { rates; standing balance; } \\
\text { lower limb strength; and } \\
\text { flexibility) } \\
\text { measured at } 12 \text { and } \\
24 \text { weeks. }\end{array}$ & $\begin{array}{l}\text { Standing balance, lower-limb strength } \\
\text { and flexibility improved in the Pilates } \\
\text { group relative to the control group } \\
(p<0.05) \text {. The rate of fall injuries at } \\
24 \text { weeks was } 42 \% \text { lower and injurious } \\
\text { fall rates } 64 \% \text { lower in the Pilates } \\
\text { group; however, it was not statistically } \\
\text { significant ( } p=0.347 \text { and } \\
p=0.136) .\end{array}$ & $\begin{array}{l}\text { Pilates exercise is an } \\
\text { enjoyable and } \\
\text { acceptable form of } \\
\text { exercise in } \\
\text { community-dwelling } \\
\text { older people at risk of } \\
\text { falling. An } \\
\text { appropriately } \\
\text { designed Pilates } \\
\text { exercise program } \\
\text { appears to improve } \\
\text { standing balance and } \\
\text { reduce the risk of falls. }\end{array}$ & $6 / 10$ \\
\hline 6 & $\begin{array}{l}\text { Filho, M.M.; } \\
\text { Vianna, J.M.; } \\
\text { Venturini, G.O.; } \\
\text { Matos, D.G.; } \\
\text { Ferreira, M.C. } \\
\text { (2016) [27] }\end{array}$ & $\begin{array}{l}\text { Assessment of } \\
\text { different exercise } \\
\text { programs on } \\
\text { muscular strength } \\
\text { and functional } \\
\text { autonomy in the } \\
\text { elderly }\end{array}$ & $\begin{array}{l}114 \\
\text { STG 22 } \\
\text { GG 23 } \\
\text { WAG24MP } \\
21 \\
\text { C } 24 \\
\text { F }\end{array}$ & $\begin{array}{l}\text { Evaluate different } \\
\text { types of physical } \\
\text { exercises: strength } \\
\text { training, } \\
\text { gymnastics, water } \\
\text { aerobics, and } \\
\text { Pilates } \\
\text { and a Control } \\
\text { Group on elderly } \\
\text { women's } \\
\text { muscular strength } \\
\text { and functional } \\
\text { autonomy. }\end{array}$ & $\begin{array}{l}\text { STG: } \\
\text { Multimuscular } \\
\text { varied sessions } \\
\text { GG:Multicomponent } \\
\text { training (flexibility, } \\
\text { strength, balance, } \\
\text { agility) } \\
\text { WAG:Aerobic and } \\
\text { muscular workout } \\
\text { MP:Pilates } \\
\text { matwork } \\
\text { C:No intervention } \\
\text { Duration: } \\
24 \text { weeks } \\
3 \times \text { week } \\
60^{\prime}\end{array}$ & $\begin{array}{l}\text { Anthropometry } \\
\text { Body Mass Index (BMI), } \\
\text { Borg Rating of Perceived } \\
\text { Exertion (RPE), } \\
\text { Physical Fitness battery } \\
\text { (Rikli and Jones, 1999). } \\
\end{array}$ & $\begin{array}{l}\text { All exercise modalities were efficient in } \\
\text { increasing muscle strength and } \\
\text { functional autonomy for the elderly } \\
\text { participants in the proposed exercise } \\
\text { programs (strength training, } \\
\text { gymnastics, water aerobics, and } \\
\text { Pilates), reinforcing the importance of } \\
\text { an active lifestyle in this population. }\end{array}$ & $\begin{array}{l}\text { Strength training } \\
\text { overcame the other } \\
\text { modalities about } \\
\text { increasing muscle } \\
\text { strength and } \\
\text { transferring its } \\
\text { physical capacity to } \\
\text { functional autonomy. }\end{array}$ & $4 / 10$ \\
\hline
\end{tabular}


Table 2. Structured summary of the studies included in the analysis (RCT).

\begin{tabular}{|c|c|c|c|c|c|c|c|c|c|}
\hline$n$ & Author & Title & $\begin{array}{l}\text { Subjects/ } \\
\text { Group }\end{array}$ & Objective & Intervention & Outcomes & Results & Conclusion(s) & $\begin{array}{c}\text { PEDro } \\
\text { Scale }\end{array}$ \\
\hline 7 & $\begin{array}{l}\text { Gabizon, H.; } \\
\text { Press, Y.; Volkov, } \\
\text { I.; Melzer, I. } \\
\text { (2016) [28] }\end{array}$ & $\begin{array}{l}\text { The Effects of } \\
\text { Pilates Training } \\
\text { on Balance } \\
\text { Control and } \\
\text { Self-Reported } \\
\text { Health Status in } \\
\text { Community- } \\
\text { Dwelling Older } \\
\text { Adults: A } \\
\text { Randomized } \\
\text { Controlled Trial }\end{array}$ & $\begin{array}{l}88 \\
\mathrm{MP} 44 \\
\mathrm{C} 44 \\
\mathrm{M} / \mathrm{F}\end{array}$ & $\begin{array}{l}\text { Evaluate the effects } \\
\text { of a Pilates-based } \\
\text { intervention balance } \\
\text { and self-perception } \\
\text { of health status. }\end{array}$ & $\begin{array}{l}\text { MP: Floor } \\
\text { Pilates } \\
\text { C: No } \\
\text { intervention } \\
\text { Duration: } 12 \\
\text { weeks } \\
\text { 3x week }\end{array}$ & $\begin{array}{l}\text { Standing upright } \\
\text { postural stability, } \\
\text { performance-based } \\
\text { measures of balance, } \\
\text { and self-reported } \\
\text { health status were } \\
\text { assessed in both } \\
\text { groups at baseline } \\
\text { and at the end of the } \\
\text { intervention period. }\end{array}$ & $\begin{array}{l}\text { Compared with the control } \\
\text { group, the Pilates intervention } \\
\text { did not improve postural } \\
\text { stability, baseline functional } \\
\text { measures of balance, or health } \\
\text { status }\end{array}$ & $\begin{array}{l}\text { The results suggest } \\
\text { that because Pilates } \\
\text { training is not task } \\
\text { specific, it does not } \\
\text { improve balance } \\
\text { control or balance } \\
\text { function in } \\
\text { independent older } \\
\text { adults. }\end{array}$ & $7 / 10$ \\
\hline 8 & $\begin{array}{l}\text { Josephs, S; Pratt, } \\
\text { M.L.; Meadows, } \\
\text { E.C.; Thurmond, } \\
\text { S.; Wagner, A. } \\
\text { (2016) [29] }\end{array}$ & $\begin{array}{l}\text { The } \\
\text { effectiveness of } \\
\text { Pilates on } \\
\text { balance and } \\
\text { falls in } \\
\text { community- } \\
\text { dwelling older } \\
\text { adults }\end{array}$ & $\begin{array}{l}24 \\
\text { MP } 13 \\
\text { C } 11 \\
\text { M/F }\end{array}$ & $\begin{array}{l}\text { Determine whether } \\
\text { Pilates is more } \\
\text { effective than } \\
\text { traditional strength } \\
\text { and balance } \\
\text { exercises for } \\
\text { improving balance } \\
\text { measures, balance } \\
\text { confidence, and } \\
\text { reducing falls in } \\
\text { community- } \\
\text { dwelling older } \\
\text { adults with fall risk. }\end{array}$ & $\begin{array}{l}\text { MP: } \\
\text { Pilates Matwork } \\
\text { C: } \\
\text { Traditional } \\
\text { exercises } \\
\text { Duration: } \\
12 \text { weeks } \\
2 x \text { week } \\
60^{\prime}\end{array}$ & $\begin{array}{l}\text { Timed Up-and-Go } \\
\text { test (TUG) } \\
\text { Balance Test (FAB) } \\
\text { Psychological } \\
\text { Questionnaire } \\
\text { (ABC) }\end{array}$ & $\begin{array}{l}\text { There was significant } \\
\text { improvement in the Fullerton } \\
\text { Advanced Balance Scale for } \\
\text { both the MP } \\
\text { (mean difference }=6.31 \text {, } \\
p<0.05 \text { ) and the Control group } \\
\text { (mean difference }=7.45 \text {, } \\
p=0.01 \text { ). The MP also showed } \\
\text { significant improvement in the } \\
\text { Activities-Specific Balance } \\
\text { Confidence Scale } \\
\text { (mean difference = 10.57, } \\
p=0.008 \text { ). }\end{array}$ & $\begin{array}{l}\text { Both Pilates and } \\
\text { traditional balance } \\
\text { programs are } \\
\text { effective at } \\
\text { improving balance } \\
\text { measures in } \\
\text { community- } \\
\text { dwelling older } \\
\text { adults with fall risk, } \\
\text { with the Pilates } \\
\text { group showing } \\
\text { improved balance } \\
\text { confidence. }\end{array}$ & $5 / 10$ \\
\hline
\end{tabular}


Table 2. Cont.

\begin{tabular}{|c|c|c|c|c|c|c|c|c|c|}
\hline$n$ & Author & Title & $\begin{array}{l}\text { Subjects/ } \\
\text { Group }\end{array}$ & Objective & Intervention & Outcomes & Results & Conclusion(s) & $\begin{array}{c}\text { PEDro } \\
\text { Scale }\end{array}$ \\
\hline 9 & $\begin{array}{l}\text { Pestana, M.S.; } \\
\text { Netto, E.M.; } \\
\text { Pestana, M.S.; } \\
\text { Pestana, V.S.; } \\
\text { Schinoni, M.I. } \\
\text { (2016) [30] }\end{array}$ & $\begin{array}{l}\text { Pilates versus } \\
\text { resistance } \\
\text { exercise on the } \\
\text { serum levels of } \\
\text { hs-CRP, in the } \\
\text { abdominal } \\
\text { circumference } \\
\text { and body mass } \\
\text { index (BMI) in } \\
\text { elderly } \\
\text { individuals }\end{array}$ & $\begin{array}{l}78 \\
\text { MP } 39 \\
\text { RT 39 } \\
\text { M/F }\end{array}$ & $\begin{array}{l}\text { Compare the effects } \\
\text { of Pilates vs. } \\
\text { resistance training } \\
\text { on seric levels of } \\
\text { highly sensitive } \\
\text { C-Protein (PCR-hs), } \\
\text { waist perimeter } \\
\text { (WP), and body } \\
\text { mass index (BMI) in } \\
\text { the elderly. }\end{array}$ & $\begin{array}{l}\text { MP: } \\
\text { Mat Pilates } \\
\text { RT: } \\
\text { Resistance } \\
\text { training }\end{array}$ & $\begin{array}{l}\text { PCR-hs } \\
\text { WP } \\
\text { BMI }\end{array}$ & $\begin{array}{l}\text { Mat Pilates reached reductions } \\
\text { in the seric levels of PCR-hs } \\
\text { (Wilcoxon signed rank; } \\
\mathrm{z}=-2.466, p=0.01 \text { ), } \\
\text { on BMI (Wilcoxon signed rank; } \\
\mathrm{z}=-3.295, p=0.001 \text { ), and in } \\
\text { WP (Wilcoxon signed rank; } \\
\mathrm{z}=-3.398, p=0.01 \text { ). } \\
\text { MP also obtained a significant } \\
\text { reduction in the seric levels of } \\
\text { PCR-hs and in the } \\
\text { anthropometric measurements. }\end{array}$ & $\begin{array}{l}\text { Pilates is more } \\
\text { effective than } \\
\text { resistance training } \\
\text { in the reduction in } \\
\text { waist perimeter and } \\
\text { body mass index. }\end{array}$ & $4 / 10$ \\
\hline 10 & $\begin{array}{l}\text { Roh, S; Yoon, } \\
\text { S.Y.; Kim, J.N.; } \\
\text { Lim, H.S. (2016) } \\
\text { [31] }\end{array}$ & $\begin{array}{l}\text { Effects of } \\
\text { modified Pilates } \\
\text { on variability of } \\
\text { inter-joint } \\
\text { coordination } \\
\text { during walking } \\
\text { in the } \\
\text { elderly }\end{array}$ & $\begin{array}{l}20 \\
\text { MP } 10 \\
\text { C } 10 \\
M / F\end{array}$ & $\begin{array}{l}\text { Examine the effects } \\
\text { of an 8-week } \\
\text { modified Pilates } \\
\text { program on the vari- } \\
\text { ability of inter-joint } \\
\text { coordination in the } \\
\text { elderly during } \\
\text { walking. }\end{array}$ & $\begin{array}{l}\text { MP: } \\
\text { Pilates Matwork } \\
\text { C: } \\
\text { No intervention } \\
\text { Duration: } \\
12 \text { weeks } \\
2 x \text { week } \\
60^{\prime}\end{array}$ & $\begin{array}{l}\text { Three-dimensional } \\
\text { motion analysis was } \\
\text { performed on both } \\
\text { groups to evaluate } \\
\text { the effects of the } \\
\text { Pilates exercise, } \\
\text { calculating the } \\
\text { continuous relative } \\
\text { phase (CRP). }\end{array}$ & $\begin{array}{l}\text { There was no significant } \\
\text { difference in the joint } \\
\text { variability of the ankle, knee, } \\
\text { and hip joints between the } \\
\text { groups, both before training } \\
\text { and after training. There was a } \\
\text { significant increase in the } \\
\text { hip-knee deviation } \\
\text { phase value in the MP and this } \\
\text { increase was also significant } \\
\text { when compared with that in } \\
\text { the control group. }\end{array}$ & $\begin{array}{l}\text { The 8-week } \\
\text { modified Pilates } \\
\text { exercise program } \\
\text { can have a positive } \\
\text { impact on the gait } \\
\text { of elderly } \\
\text { participants, } \\
\text { potentially by } \\
\text { enhancing } \\
\text { neuromuscular } \\
\text { adjustment, which } \\
\text { may have positive } \\
\text { implications for } \\
\text { reducing their fall } \\
\text { risk. }\end{array}$ & $5 / 10$ \\
\hline
\end{tabular}


Table 2. Cont.

\begin{tabular}{|c|c|c|c|c|c|c|c|c|c|}
\hline$n$ & Author & Title & $\begin{array}{l}\text { Subjects/ } \\
\text { Group }\end{array}$ & Objective & Intervention & Outcomes & Results & Conclusion(s) & $\begin{array}{c}\text { PEDro } \\
\text { Scale }\end{array}$ \\
\hline 11 & $\begin{array}{l}\text { Badiei, M.; } \\
\text { Shahboulaghi, } \\
\text { F.M.; Hosseini, } \\
\text { M.; Noroozi, M.; } \\
\text { Nazari, S. (2017) } \\
\text { [32] }\end{array}$ & $\begin{array}{l}\text { Effect of Pilates } \\
\text { Exercise on Fear } \\
\text { of Falling } \\
\text { in Iranian } \\
\text { Elderly Women }\end{array}$ & $\begin{array}{l}44 \\
\text { MP } 22 \\
\text { C } 22 \\
\text { F }\end{array}$ & $\begin{array}{l}\text { Determine the effect } \\
\text { of Pilates exercise } \\
\text { on Fear of } \\
\text { Falling (FOF) } \\
\text { among elderly } \\
\text { women. }\end{array}$ & $\begin{array}{l}\text { MP: } \\
\text { Pilates Matwork } \\
\text { C: } \\
\text { Normal } \\
\text { stretching } \\
\text { training } \\
\text { Duration: } \\
8 \text { weeks } \\
\text { 3x week } \\
60^{\prime}\end{array}$ & $\begin{array}{l}\text { Data were gathered } \\
\text { by using } \\
\text { demographic } \\
\text { questionnaire and } \\
\text { Fall Efficacy } \\
\text { Scale-International } \\
\text { (FES-I). }\end{array}$ & $\begin{array}{l}\text { FES-I scores in Pilates group } \\
\text { improved from } \\
32.90 \text { to } 22.18(\mathrm{MD}=10.72) \\
\text { after the intervention. } \\
\text { According to the independent } \\
t \text {-test, there } \\
\text { was a significant difference in } \\
\text { the means of post-intervention } \\
\text { FES-I scores between the two } \\
\text { groups }(p<0.001) \text {. In the } \\
\text { Pilates group, the effect size of } \\
\text { intervention was much more } \\
\text { than the control group } \\
(\mathrm{ES}=0.89) .\end{array}$ & $\begin{array}{l}\text { Pilates training } \\
\text { could decrease the } \\
\text { FOF and may thus } \\
\text { be implemented as } \\
\text { an effective } \\
\text { interventional } \\
\text { method for fall } \\
\text { prevention in } \\
\text { elderly women. }\end{array}$ & $6 / 10$ \\
\hline 12 & $\begin{array}{l}\text { Carvalho, F.T.; } \\
\text { Mesquita, L.A.; } \\
\text { Pereira, R.; Neto, } \\
\text { O.P.; Zangaro, } \\
\text { R.A. (2017) [33] }\end{array}$ & $\begin{array}{l}\text { Pilates and } \\
\text { Proprioceptive } \\
\text { Neuromuscular } \\
\text { Facilitation } \\
\text { Methods Induce } \\
\text { Similar Strength } \\
\text { Gains but } \\
\text { Different } \\
\text { Neuromuscular } \\
\text { Adaptations in } \\
\text { Elderly Women }\end{array}$ & $\begin{array}{l}60 \\
\text { MP 20 } \\
\text { PNF } 20 \\
\text { C } 20 \\
\text { F }\end{array}$ & $\begin{array}{l}\text { To compare the } \\
\text { influence of a } \\
\text { training period with } \\
\text { Pilates and } \\
\text { Proprioceptive } \\
\text { Neuromuscular } \\
\text { Facilitation (PNF) } \\
\text { methods on } \\
\text { strength gains and } \\
\text { motor control } \\
\text { adaptations during } \\
\text { voluntary } \\
\text { contraction, applied } \\
\text { to a group of elderly } \\
\text { women. }\end{array}$ & $\begin{array}{l}\text { MP: } \\
\text { Pilates Matwork } \\
\text { PNF: } \\
\text { PNF training } \\
\text { Duration: } \\
4 \text { weeks } \\
\text { 3x week } \\
50^{\prime}\end{array}$ & $\begin{array}{l}\text { Isometric Force } \\
\text { Acquisition } \\
\text { EMG Measurement } \\
\text { Fluctuations in } \\
\text { Motor Output }\end{array}$ & $\begin{array}{l}\text { One-way analysis of variance } \\
\text { indicated no differences among } \\
\text { groups for all variables (i.e., } \\
\text { isometric force, force } \\
\text { fluctuation, and force and EMG } \\
\text { spectral features) at } \\
\text { pre-training moment ( } p>0.05 \text { ). } \\
\text { Isometric muscle force from } \\
\text { knee extensors (KE) and flexors } \\
\text { (KF) showed significant main } \\
\text { effect for groups (F2,56 = 6.77, } \\
p=0.002 \text { from KE; F2,56 = 3.72, } \\
p=0.03 \text { from KF), for measure } \\
(\mathrm{F} 1,56=23.08, p<0.0001 \text { from } \\
\text { KE; F1,56 } 21.23, p<0.0001 \\
\text { from KF), and a significant } \\
\text { Group } \times \text { Measure interaction } \\
(\mathrm{F} 2,56=19.97, p<0.0001 \text { from } \\
\text { KE; F2,56 = 6.65, } p=0.003 \text { from } \\
\text { KF). }\end{array}$ & $\begin{array}{l}\text { These results } \\
\text { support use of both } \\
\text { Pilates and PNF } \\
\text { methods to enhance } \\
\text { lower limb muscle } \\
\text { strength in older } \\
\text { groups, which is } \\
\text { very important for } \\
\text { gait, postural } \\
\text { stability, and } \\
\text { performance of } \\
\text { daily life activities. }\end{array}$ & $5 / 10$ \\
\hline
\end{tabular}


Table 3. Structured summary of the studies included in the analysis (RCT).

\begin{tabular}{|c|c|c|c|c|c|c|c|c|c|}
\hline$n$ & Author & Title & $\begin{array}{l}\text { Subjects/ } \\
\text { Group }\end{array}$ & Objective & Intervention & Outcomes & Results & Conclusion(s) & $\begin{array}{l}\text { PEDro } \\
\text { Scale }\end{array}$ \\
\hline 13 & $\begin{array}{l}\text { Jurakic, Z.G.; } \\
\text { Krizanic, V.; } \\
\text { Sarabon, N.; } \\
\text { Markovic, G. } \\
\text { (2017) [34] }\end{array}$ & $\begin{array}{l}\text { Effects of } \\
\text { feedback-based } \\
\text { balance and core } \\
\text { resistance training } \\
\text { vs. Pilates training } \\
\text { on cognitive } \\
\text { functions in older } \\
\text { women with mild } \\
\text { cognitive } \\
\text { impairment: a pilot } \\
\text { randomized } \\
\text { controlled trial }\end{array}$ & $\begin{array}{l}28 \\
\text { MP 14 } \\
\text { CRT14 } \\
\text { F }\end{array}$ & $\begin{array}{l}\text { Provide preliminary } \\
\text { evidence } \\
\text { on the effects of two } \\
\text { types of non-aerobic } \\
\text { training on } \\
\text { cognitive functions } \\
\text { in older women } \\
\text { suffering from MCI } \\
\text { (mild cognitive } \\
\text { impairment). }\end{array}$ & $\begin{array}{l}\text { MP:Pilates } \\
\text { Matwork } \\
\text { CRT:Core } \\
\text { Resistance } \\
\text { Training } \\
\text { Duration: } \\
8 \text { weeks } \\
3 x \text { week } \\
60^{\prime}\end{array}$ & $\begin{array}{l}\text { Assessing tool } \\
\text { MCI: MoCA }\end{array}$ & $\begin{array}{l}\text { CRT group obtained significant } \\
\text { improvements in score of } \\
\text { visuospatial/executive } \\
\text { functions and orientation as } \\
\text { well as global score compared } \\
\text { with MP. } \\
\text { Significant improvement in } \\
\text { short-term memory-recall task } \\
\text { was obtained only in the MP. }\end{array}$ & $\begin{array}{l}\text { Non-aerobic training } \\
\text { should be further } \\
\text { explored as a } \\
\text { beneficial } \\
\text { intervention for older } \\
\text { adults suffering from } \\
\text { MCI. }\end{array}$ & $5 / 10$ \\
\hline 14 & $\begin{array}{l}\text { Oliveira, L.C.; } \\
\text { Pires-Oliveira, } \\
\text { D.A.; Abucarub, } \\
\text { A.C.; Oliveira, } \\
\text { L.S.; Oliveira, } \\
\text { R.G. (2017) [35] }\end{array}$ & $\begin{array}{l}\text { Pilates increases } \\
\text { isokinetic muscular } \\
\text { strength of the } \\
\text { elbow flexor and } \\
\text { extensor muscles of } \\
\text { older women: A } \\
\text { randomized } \\
\text { controlled clinical } \\
\text { trial }\end{array}$ & $\begin{array}{l}30 \\
\text { PA } 15 \\
\text { C } 15 \\
\text { M/F }\end{array}$ & $\begin{array}{l}\text { Verify the influence } \\
\text { of Pilates in the } \\
\text { isokinetic strength } \\
\text { of the elbow } \\
\text { extensors and } \\
\text { flexors, as well as } \\
\text { upper limb } \\
\text { functionality }\end{array}$ & $\begin{array}{l}\text { PA: Pilates } \\
\text { apparatus } \\
\text { C: Maintenance } \\
\text { of routines } \\
\text { Duration: } \\
12 \text { weeks } \\
2 x \text { week } \\
60^{\prime}\end{array}$ & $\begin{array}{l}\text { Elbow extensor } \\
\text { and flexor } \\
\text { strength } \\
\text { (dynamometer) } \\
\text { Functional test } \\
\text { (dress and } \\
\text { undress a } \\
\text { t-shirt) }\end{array}$ & $\begin{array}{l}\text { In the intra-group comparison, } \\
\text { the PA improved strength of } \\
\text { the elbow extensors and the } \\
\text { functionality of the upper } \\
\text { limbs }(p<0.05) \text {. When } \\
\text { comparing the } \\
\text { post-intervention moment, the } \\
\text { PA was superior to the } C \text { in all } \\
\text { variables }(p<0.05) \text {, with a large } \\
\text { effect size }(\mathrm{d}>0.80) \text {. }\end{array}$ & $\begin{array}{l}\text { It was observed that } \\
\text { the Pilates method } \\
\text { can contribute to } \\
\text { improving the } \\
\text { isokinetic muscular } \\
\text { strength of the elbow } \\
\text { flexors and extensors, } \\
\text { as well as the } \\
\text { functionality of the } \\
\text { upper limbs. }\end{array}$ & $8 / 10$ \\
\hline
\end{tabular}


Table 3. Cont.

\begin{tabular}{|c|c|c|c|c|c|c|c|c|c|}
\hline$n$ & Author & Title & $\begin{array}{l}\text { Subjects/ } \\
\text { Group }\end{array}$ & Objective & Intervention & Outcomes & Results & Conclusion(s) & $\begin{array}{c}\text { PEDro } \\
\text { Scale }\end{array}$ \\
\hline 15 & $\begin{array}{l}\text { Oliveira, L.C.; } \\
\text { Oliveira, R.G.; } \\
\text { Pires-Oliveira, } \\
\text { D.A. (2017) [36] }\end{array}$ & $\begin{array}{l}\text { Pilates increases } \\
\text { isokinetic muscular } \\
\text { strength of the knee } \\
\text { flexor and extensor } \\
\text { muscles of older } \\
\text { women }\end{array}$ & $\begin{array}{l}32 \\
\text { PA } 16 \\
\text { SS } 16 \\
\text { F }\end{array}$ & $\begin{array}{l}\text { Verify the influence } \\
\text { of Pilates in the } \\
\text { isokinetic strength } \\
\text { of the knee } \\
\text { extensors and } \\
\text { flexors at } 60^{\circ} \text {. }\end{array}$ & $\begin{array}{l}\text { PA: Pilates } \\
\text { apparatus } \\
\text { SS: static } \\
\text { stretching } \\
\text { Duration: } \\
12 \text { weeks } \\
2 x \text { week } \\
60^{\prime}\end{array}$ & $\begin{array}{l}\text { Knee extensor } \\
\text { and flexor } \\
\text { strength } \\
\text { (dynamometer) }\end{array}$ & $\begin{array}{l}\text { The SS presented a significant } \\
\text { improvement }(p<0.01) \text { in all } \\
\text { tests performed, when } \\
\text { comparing the pre- and } \\
\text { post-intervention (intragroup) } \\
\text { (Cohen's } \mathrm{d}=2.03 \text { and } 1.33 \text { for } \\
\text { the knee flexor and extensor } \\
\text { muscles, respectively). } \\
\text { Comparing the C and SS } \\
\text { (intergroup), post-intervention, } \\
\text { a significant improvement was } \\
\text { observed ( } p<0.01 \text { ) in favor of } \\
\text { the SS for all variables (Cohen's } \\
\mathrm{d}=1.59 \text { and } 1.15 \text { for the knee } \\
\text { flexor and extensor muscles, } \\
\text { respectively. }\end{array}$ & $\begin{array}{l}\text { The results indicated } \\
\text { that } 12 \text { weeks of } \\
\text { Pilates increases the } \\
\text { isokinetic muscular } \\
\text { strength of the knee } \\
\text { extensors and flexors } \\
\text { in elderly women and } \\
\text { can be considered for } \\
\text { this purpose when } \\
\text { prescribing physical } \\
\text { exercise programs. }\end{array}$ & $8 / 10$ \\
\hline 16 & $\begin{array}{l}\text { Sofianidis, G; } \\
\text { Dimitriou, A.; } \\
\text { Hatzitaki, V. } \\
\text { (2017) [37] }\end{array}$ & $\begin{array}{l}\text { A Comparative } \\
\text { Study of the Effects } \\
\text { of Pilates and Latin } \\
\text { Dance on Static and } \\
\text { Dynamic Balance in } \\
\text { Older Adults }\end{array}$ & $\begin{array}{l}36 \\
\text { MP } 12 \\
\text { LD } 12 \\
\text { C } 12 \\
\text { M/F }\end{array}$ & $\begin{array}{l}\text { Compare the } \\
\text { efficiency of Pilates } \\
\text { intervention and } \\
\text { Latin Dances in } \\
\text { static and dynamic } \\
\text { balance of the } \\
\text { elderly. }\end{array}$ & $\begin{array}{l}\text { MP: } \\
\text { Mat Pilates } \\
\text { LD: } \\
\text { Latin Dances } \\
\text { C: } \\
\text { No intervention } \\
\text { Duration: } \\
12 \text { weeks } \\
2 x \text { week } \\
60^{\prime}\end{array}$ & $\begin{array}{l}\text { Center of } \\
\text { Pressure (CoP) } \\
\text { Trunk Angular } \\
\text { Variability } \\
\text { "Two-Leg } \\
\text { Tandem Stance" } \\
\text { with eyes open } \\
\text { and closed } \\
\text { "One Leg } \\
\text { Stance" (OLS) } \\
\text { with the eyes } \\
\text { open } \\
\text { Dynamic } \\
\text { balance } \\
\text { "Periodic } \\
\text { balance" with } \\
\text { and without } \\
\text { guiding sound }\end{array}$ & $\begin{array}{l}\text { The results of trunk swinging } \\
\text { during the "Two-Leg Tandem } \\
\text { Stance" with eyes closed, } \\
\text { reduction on CoP displacement } \\
\text { during the "One leg Stance" } \\
\text { and the increase in trunk } \\
\text { oscilation in the trunk } \\
\text { swinging test for both } \\
\text { intervention groups. }\end{array}$ & $\begin{array}{l}\text { Both programs had a } \\
\text { positive effect in the } \\
\text { static and dynamic } \\
\text { balance-related } \\
\text { variables. LD appears } \\
\text { to be better for people } \\
\text { with rhythm } \\
\text { perception and } \\
\text { sensorimotor control. } \\
\text { On the other hand, } \\
\text { Pilates appears to be } \\
\text { more effective for } \\
\text { people with trunk } \\
\text { control problems, as it } \\
\text { improves core } \\
\text { stability. }\end{array}$ & $4 / 10$ \\
\hline
\end{tabular}


Table 3. Cont.

\begin{tabular}{|c|c|c|c|c|c|c|c|c|c|}
\hline$n$ & Author & Title & $\begin{array}{l}\text { Subjects/ } \\
\text { Group }\end{array}$ & Objective & Intervention & Outcomes & Results & Conclusion(s) & $\begin{array}{c}\text { PEDro } \\
\text { Scale }\end{array}$ \\
\hline 17 & $\begin{array}{l}\text { Vieira, N.D.; } \\
\text { Testa, D.; Ruas, } \\
\text { P.C.; Salvini, T.F.; } \\
\text { Catai, A.M.; } \\
\text { Melo, R.C. } \\
\text { (2017) [38] }\end{array}$ & $\begin{array}{l}\text { The effects of } 12 \\
\text { weeks } \\
\text { Pilates-inspired } \\
\text { exercise training on } \\
\text { functional } \\
\text { performance in } \\
\text { older women: A } \\
\text { randomized clinical } \\
\text { trial }\end{array}$ & $\begin{array}{l}40 \\
\text { MP } 21 \\
\text { C } 19 \\
\text { F }\end{array}$ & $\begin{array}{l}\text { Investigate the } \\
\text { effects of a 12-week } \\
\text { Pilates-inspired } \\
\text { program in the } \\
\text { functional } \\
\text { performance of } \\
\text { elderly people in } \\
\text { nursing homes. }\end{array}$ & $\begin{array}{l}\text { MP:Mat Pilates } \\
\text { C:No } \\
\text { intervention } \\
\text { Duration: } \\
12 \text { weeks } \\
2 x \text { week } \\
60^{\prime}\end{array}$ & $\begin{array}{l}\text { (OLS) } \\
\text { Timed } \\
\text { Up-and-Go Test } \\
\text { (TUG) } \\
\text { five-time-sit-to- } \\
\text { stand (STS) } \\
6 \text { min walk } \\
(6 \mathrm{MW})\end{array}$ & $\begin{array}{l}\text { After the intervention, } \\
\text { significant differences were } \\
\text { found in the time to complete } \\
\text { the tasks: STS }(p=0.03) \text { e } \\
6 \mathrm{MW}(p<0.01) \text {. Only the MP } \\
\text { improved the STS }(p=0.02) \\
\text { and the } 6 \text { MW test }(p<0.01) \text {. }\end{array}$ & $\begin{array}{l}\text { Pilates-based } \\
\text { exercises improve } \\
\text { balance, lower limb } \\
\text { strength and aerobic } \\
\text { resistance in elderly } \\
\text { ladies in nursing } \\
\text { homes. }\end{array}$ & $5 / 10$ \\
\hline 18 & $\begin{array}{l}\text { Alvarenga, } \\
\text { G.M.; } \\
\text { Charkovsky, } \\
\text { S.A.; Santos, } \\
\text { L.K.; Silva, M.B.; } \\
\text { Tomaz, G.O.; } \\
\text { Gamba, H.R. } \\
\text { (2018) [39] }\end{array}$ & $\begin{array}{l}\text { The influence of } \\
\text { inspiratory muscle } \\
\text { training combined } \\
\text { with the Pilates } \\
\text { method on lung } \\
\text { function in elderly } \\
\text { women: a } \\
\text { randomized } \\
\text { controlled trial }\end{array}$ & $\begin{array}{l}31 \\
\text { MP + TI } 11 \\
\text { PA } 11 \\
\text { C } 9 \\
\text { F }\end{array}$ & $\begin{array}{l}\text { Assess the influence } \\
\text { of inspiratory } \\
\text { muscle training } \\
\text { combined with } \\
\text { Pilates in the } \\
\text { pulmonar function } \\
\text { of elderly women. }\end{array}$ & $\begin{array}{l}\text { MP + TI (Pilates } \\
\text { Group + } \\
\text { Inspiratory } \\
\text { training) } \\
\text { PA: Pilates } \\
\text { Apparatus } \\
\text { C: No } \\
\text { intervention } \\
\text { Duration: } \\
2 x \text { week } \\
45^{\prime} \\
10 \text { weeks }\end{array}$ & $\begin{array}{l}\text { Spirometry } \\
\text { manuvacuometry } \\
6 \text { min test } \\
\text { Curl-Up Test } \\
\text { Pulmonary } \\
\text { variables }\end{array}$ & $\begin{array}{l}\text { Improvements in the strength } \\
\text { of muscles in maximal } \\
\text { inhalation and in pressure and } \\
\text { power }(p<0.0001) \text {, in the } \\
\text { muscular strength on maximal } \\
\text { exhalation }(p<0.0014) \text {, in the } \\
\text { performance of the } 6 \text { min test } \\
(p<0.01) \text {, and in the Curl-Up } \\
\text { test }(p<0.00001) \text {. }\end{array}$ & $\begin{array}{l}\text { Pilates combined with } \\
\text { technological } \\
\text { equipment that } \\
\text { allows the analysis, } \\
\text { treatment, and } \\
\text { training of the } \\
\text { pulmonar function } \\
\text { showed efficacy in } \\
\text { this type of } \\
\text { application. }\end{array}$ & $5 / 10$ \\
\hline
\end{tabular}


Table 4. Structured summary of the studies included in the analysis (RCT).

\begin{tabular}{|c|c|c|c|c|c|c|c|c|c|}
\hline$n$ & Author & Title & $\begin{array}{l}\text { Subjects/ } \\
\text { Group }\end{array}$ & Objective & Intervention & Outcomes & Results & Conclusion(s) & $\begin{array}{c}\text { PEDro } \\
\text { Scale }\end{array}$ \\
\hline 19 & $\begin{array}{l}\text { Curi, V.S.; Haas, } \\
\text { A.N.; } \\
\text { Alves-Vilaça, J.; } \\
\text { Fernandes, H.M. } \\
\text { (2018) [40] }\end{array}$ & $\begin{array}{l}\text { Effects of } \\
16 \text {-weeks of } \\
\text { Pilates on } \\
\text { functional } \\
\text { autonomy and } \\
\text { life satisfaction } \\
\text { among elderly } \\
\text { women }\end{array}$ & $\begin{array}{l}61 \\
\text { MP } 31 \\
\text { C } 30 \\
\text { F }\end{array}$ & $\begin{array}{l}\text { Determine the } \\
\text { effects of Mat } \\
\text { Pilates on the } \\
\text { functional } \\
\text { autonomy and } \\
\text { life satisfaction } \\
\text { of the elderly. }\end{array}$ & $\begin{array}{l}\text { MP: Mat Pilates } \\
\text { C: No } \\
\text { intervention } \\
\text { Duration: } \\
16 \text { weeks } \\
2 x \text { week } \\
60^{\prime}\end{array}$ & $\begin{array}{l}\text { Rikli and Jones Protocol } \\
\text { (2002) } \\
\text { Satisfaction with life }\end{array}$ & $\begin{array}{l}\text { Statistically significant } \\
\text { differences were found in all } \\
\text { parameters: lower limb } \\
\text { strength and flexibility, upper } \\
\text { limb strength and flexibility, } \\
\text { dynamic balance, aerobic } \\
\text { resistance, and satisfaction } \\
\text { with life. }\end{array}$ & $\begin{array}{l}\text { Functional autonomy } \\
\text { and satisfaction with } \\
\text { life were improved } \\
\text { with the intervention, } \\
\text { suggesting that } \\
\text { Pilates helps in active } \\
\text { ageing. }\end{array}$ & $5 / 10$ \\
\hline 20 & $\begin{array}{l}\text { Curi, V.S.; Haas, } \\
\text { A.N.; } \\
\text { Alves-Vilaça, J.; } \\
\text { Fernandes, H.M. } \\
\text { (2018) [41] }\end{array}$ & $\begin{array}{l}\text { Effects of } \\
\text { 16-weeks of } \\
\text { Pilates on health } \\
\text { perception and } \\
\text { sleep quality } \\
\text { among elderly } \\
\text { women }\end{array}$ & $\begin{array}{l}61 \\
\text { MP } 31 \\
\text { C } 30 \\
\text { F }\end{array}$ & $\begin{array}{l}\text { Determine the } \\
\text { effects of Mat } \\
\text { Pilates on the } \\
\text { perception and } \\
\text { sleep quality of } \\
\text { elderly. }\end{array}$ & $\begin{array}{l}\text { MP: Mat Pilates } \\
\text { C: No } \\
\text { intervention } \\
\text { Duration: } \\
16 \text { weeks } \\
2 x \text { week } \\
60^{\prime}\end{array}$ & $\begin{array}{l}\text { General Health } \\
\text { Questionnaire } \\
\text { (GHQ-12) } \\
\text { Pittsburgh Sleep } \\
\text { Quality Index } \\
\text { (PSQI-BR) }\end{array}$ & $\begin{array}{l}\text { Statistically significant } \\
\text { differences were found in the } \\
\text { following parameters: } \\
\text { GHQ-12 total score }(p<0.001 \\
\left.\eta^{2}=0.19\right) \\
\text { Depression sub-scale }(p<0.002, \\
\left.\eta^{2}=0.15\right) \\
\text { Social disfunction Sub-scale } \\
\left(p<0.001, \eta^{2}=0.18\right) \\
\text { PSQI-BR total score }(p<0.017 \\
\left.\eta^{2}=0.09\right) \\
\text { sleep latency ( } p<0.023 \\
\left.\eta^{2}=0.09\right) \text { and Use of } \\
\text { medication sub-scale }(p<0.019 \\
\left.\eta^{2}=0.09\right)\end{array}$ & $\begin{array}{l}\text { Health perception } \\
\text { and other sleep } \\
\text { quality parameters } \\
\text { improved with } \\
\text { Pilates. }\end{array}$ & $5 / 10$ \\
\hline
\end{tabular}


Table 4. Cont.

\begin{tabular}{|c|c|c|c|c|c|c|c|c|c|}
\hline$n$ & Author & Title & $\begin{array}{l}\text { Subjects/ } \\
\text { Group }\end{array}$ & Objective & Intervention & Outcomes & Results & Conclusion(s) & $\begin{array}{c}\text { PEDro } \\
\text { Scale }\end{array}$ \\
\hline 21 & $\begin{array}{l}\text { Roller, M.; } \\
\text { Kachingwe, A.; } \\
\text { Beling, J.; Ickes, } \\
\text { D.; Cabot, A.; } \\
\text { Shrier, G. (2018) } \\
\text { [42] }\end{array}$ & $\begin{array}{l}\text { Pilates Reformer } \\
\text { exercises for fall } \\
\text { risk reduction in } \\
\text { older adults: A } \\
\text { randomized } \\
\text { controlled trial }\end{array}$ & $\begin{array}{l}57 \\
\text { PA } 27 \\
\text { C } 28 \\
M / F\end{array}$ & $\begin{array}{l}\text { Investigate the } \\
\text { effects of Pilates } \\
\text { using a } \\
\text { Reformer in the } \\
\text { fall risk, balance } \\
\text { and mobility, } \\
\text { self-efficacy, and } \\
\text { active range of } \\
\text { motion. }\end{array}$ & $\begin{array}{l}\text { PA: Pilates in } \\
\text { the Reformer } \\
\text { C: } \\
\text { no intervention } \\
\text { Duration: } \\
10 \text { weeks } \\
1 \times \text { week } \\
45^{\prime}\end{array}$ & $\begin{array}{l}\text { Balance: } \\
\text { "Sensory Organization } \\
\text { Test and Adaptation } \\
\text { Test" (SOT) and (ADT) } \\
\text { "Timed Up-and-Go } \\
\text { Test" (TUG) } \\
\text { "Berg Balance Scale" } \\
\text { (BBS) } \\
\text { "Ten-meter walk test" } \\
\text { (10 MTW) } \\
\text { "Activities-specific } \\
\text { Balance Confidence } \\
\text { Scale" (ABC) } \\
\text { Active range of motion: } \\
\text { Straight Leg Raise (SLR) } \\
\text { Hip Extension (HE) } \\
\text { Ankle Dorsiflexion } \\
\text { (AD) }\end{array}$ & $\begin{array}{l}\text { An interaction between group } \\
\text { and time in TUG, BBS, } 10 \mathrm{MWT} \\
\text { and SLR, HE, and AD. With } \\
\text { time, PA significantly } \\
\text { improved in all balance } \\
\text { measurements ( } p \leq 0.005 \text { ). } \\
\text { Improvements in active range } \\
\text { of motion were found after the } \\
\text { intervention for SLR (left) and } \\
\text { AD (right). }\end{array}$ & $\begin{array}{l}\text { Pilates Reformer done } \\
\text { once per week for } 10 \\
\text { weeks resulted in } \\
\text { fall-risk reduction and } \\
\text { significant } \\
\text { improvements in the } \\
\text { dynamic and static } \\
\text { balance, functional } \\
\text { mobility, self efficacy } \\
\text { in balance and in } \\
\text { lower limb range of } \\
\text { motion. Pilates } \\
\text { Reformer exercises } \\
\text { are more effective } \\
\text { than no exercises for } \\
\text { improvements in the } \\
\text { hip and ankle range } \\
\text { of motion } \geq \text {. }\end{array}$ & $6 / 10$ \\
\hline 22 & $\begin{array}{l}\text { Tozim, B.M.; } \\
\text { Navega, M.T. } \\
\text { (2018) [43] }\end{array}$ & $\begin{array}{l}\text { Effect of Pilates } \\
\text { method on } \\
\text { inspiratory and } \\
\text { expiratory } \\
\text { muscle strength } \\
\text { in the elderly }\end{array}$ & $\begin{array}{l}31 \\
\text { MP } 14 \\
\text { C } 17 \\
\text { F }\end{array}$ & $\begin{array}{l}\text { Analyse the } \\
\text { influence of } \\
\text { Pilates on } \\
\text { respiratory } \\
\text { strength in the } \\
\text { elderly. }\end{array}$ & $\begin{array}{l}\text { MP: } \\
\text { Pilates matwork } \\
\text { C: } \\
\text { Educational } \\
\text { sessions } \\
\text { Duration: } \\
8 \text { weeks } \\
2 x \text { week } \\
60^{\prime}\end{array}$ & $\begin{array}{l}\text { Maximal inspiratory } \\
\text { Force } \\
\text { (Pimax) } \\
\text { Maximal expiratory } \\
\text { Force } \\
\text { (Pemax) }\end{array}$ & $\begin{array}{l}\text { Significant differences were } \\
\text { found with average effect size } \\
\text { for the strength of the } \\
\text { expiratory muscles in the MP } \\
\text { when comparing pre- and post- } \\
(p<0.05) \text { intervention } \\
(69.71 \pm 25.48 \text { e } 85.23 \pm 22.21 \\
\text { respectively). }\end{array}$ & $\begin{array}{l}\text { Pilates is effective in } \\
\text { the improvement of } \\
\text { expiratory muscle } \\
\text { strength and presents } \\
\text { a positive effect on } \\
\text { the increase in the } \\
\text { inspiratory muscle } \\
\text { strength. }\end{array}$ & $5 / 10$ \\
\hline
\end{tabular}


Table 4. Cont.

\begin{tabular}{|c|c|c|c|c|c|c|c|c|c|}
\hline$n$ & Author & Title & $\begin{array}{l}\text { Subjects/ } \\
\text { Group }\end{array}$ & Objective & Intervention & Outcomes & Results & Conclusion(s) & $\begin{array}{c}\text { PEDro } \\
\text { Scale }\end{array}$ \\
\hline 23 & $\begin{array}{l}\text { Aibar-Almazán, } \\
\text { A.; } \\
\text { Martínez-Amat, } \\
\text { A.; Cruz-Díaz, } \\
\text { D.; Torre-Cruz, } \\
\text { M.J.; } \\
\text { Jiménez-Garcia, } \\
\text { J.D.; } \\
\text { Zagalaz-Anula, } \\
\text { N; Pérez- } \\
\text { Herrezuelo, I.; } \\
\text { Hita-Contreras, } \\
\text { F. (2019) [44] }\end{array}$ & $\begin{array}{l}\text { Effects of Pilates } \\
\text { on fall risk } \\
\text { factors in } \\
\text { community- } \\
\text { dwelling elderly } \\
\text { women: a } \\
\text { randomized, } \\
\text { controlled trial }\end{array}$ & $\begin{array}{l}110 \\
\text { MP } 55 \\
\text { C } 52 \\
\text { F }\end{array}$ & $\begin{array}{l}\text { Analyse the } \\
\text { effect of Pilates } \\
\text { on the } \\
\text { confidence of } \\
\text { balance, fear of } \\
\text { falling, and } \\
\text { postural control. }\end{array}$ & $\begin{array}{l}\text { MP: 1x week } \\
60^{\prime} \\
\text { C: } \\
\text { No intervention } \\
\text { Duration.12 } \\
\text { weeks }\end{array}$ & $\begin{array}{l}\text { Falls Efficacy } \\
\text { Scale-International } \\
\text { (FES-I) } \\
\text { Activity-specific } \\
\text { balance confidence } \\
\text { scale (ABS) } \\
\text { Stabilizing platform }\end{array}$ & $\begin{array}{l}\text { MP presents higher values in } \\
\text { the confidence of balance when } \\
\text { compared with the C } \\
\text { ( } 77.52 \pm 18.27 \text { vs. } \\
72.35 \pm 16.39 \text {, } \\
\text { Cohen's } d=0.030) \text {, as well as } \\
\text { in fear of falling ( } 22.07 \pm 5.73 \\
\text { vs. } 27.9 \pm 6.95 \\
\text { Cohen's } d=0.041) \text {. } \\
\text { MP significantly improved the } \\
\text { speed and antero-posterior } \\
\text { movements of the center of } \\
\text { pressure with both open and } \\
\text { closed eyes } \\
\text { (Cohen's } d=0.44 \text { e } 0.35 \text {, } \\
\text { respectively). }\end{array}$ & $\begin{array}{l}\text { A 12-week Pilates } \\
\text { intervention is } \\
\text { beneficial for the } \\
\text { confidence in balance, } \\
\text { fear of falling, and } \\
\text { postural stability in } \\
\text { elderly women. }\end{array}$ & $8 / 10$ \\
\hline 24 & $\begin{array}{l}\text { Liposcki, D.B.; } \\
\text { Nagata, I.S.; } \\
\text { Silvano, G.A.; } \\
\text { Zanella, K.; } \\
\text { Schneider, R.H. } \\
\text { (2019) [45] }\end{array}$ & $\begin{array}{l}\text { Influence of a } \\
\text { Pilates exercise } \\
\text { program on the } \\
\text { quality of life of } \\
\text { sedentary } \\
\text { elderly people: } \\
\text { A randomized } \\
\text { clinical trial }\end{array}$ & $\begin{array}{l}24 \\
\text { PA } 9 \\
\text { C } 11 \\
\text { F }\end{array}$ & $\begin{array}{l}\text { Assess the } \\
\text { influence of } \\
\text { Pilates on } \\
\text { quality of life of } \\
\text { sedentary } \\
\text { elderly people. }\end{array}$ & $\begin{array}{l}\text { PA: Pilates } \\
\text { Group: } \\
\text { Mat and } \\
\text { apparatus } \\
\text { C (Control): } \\
\text { Normal routine } \\
\text { Duration: } \\
6 \text { months } \\
2 \times \text { week } \\
30^{\prime}\end{array}$ & QOL SF-36 & $\begin{array}{l}\text { MP improved in } 7 \text { of the } 8 \\
\text { domains of this study: } \\
\text { functional capacity }(91.6 \pm 14.3 \\
\text { vs. } 62.6 \pm 24.4 ; p \leq 0.01) ; \\
\text { physical aspect }(92.7 \pm 14.8 \text { vs. } \\
52.2 \pm 43.9 ; p=0.03) ; \text { pain } \\
(95.7 \pm 6.9 \text { vs. } 52.2 \pm 17.5 \\
p \leq 0.01) ; \text { General health status } \\
(89.4 \pm 11.2 \text { vs. } 76.7 \pm 16.3 ; \\
p=0.04) ; \text { Vitality }(85.5 \pm 13.5 \\
\text { vs. } 70.0 \pm 14.9 ; p=0.04) ; \text { Social } \\
\text { aspects }(97.2 \pm 8.3 \text { vs. } \\
77.9 \pm 23.9 ; p=0.03) ; \text { and } \\
\text { mental health }(77.52 \pm 18.27 \text { vs. } \\
72.35 \pm 16.39 ; p=0.05) .\end{array}$ & $\begin{array}{l}\text { Results show that } \\
\text { implementing a } \\
\text { Pilates program may } \\
\text { improve the quality } \\
\text { of life of sedentary } \\
\text { elderly people. }\end{array}$ & $4 / 10$ \\
\hline
\end{tabular}


Table 5. Structured summary of the studies included in the analysis (RCT).

\begin{tabular}{|c|c|c|c|c|c|c|c|c|c|}
\hline$n$ & Author & Title & $\begin{array}{l}\text { Subjects/ } \\
\text { Group }\end{array}$ & Objective & Intervention & Outcomes & Results & Conclusion(s) & $\begin{array}{c}\text { PEDro } \\
\text { Scale }\end{array}$ \\
\hline 25 & $\begin{array}{l}\text { García-Garro, } \\
\text { p.A.; } \\
\text { Hita-Contreras, F.; } \\
\text { Martínez-Amat, } \\
\text { A.; } \\
\text { Achalandabaso- } \\
\text { Ochoa, A.; } \\
\text { Jiménez-García, } \\
\text { J.D.; Cruz-Díaz, } \\
\text { D.; } \\
\text { Aibar-Almazán, A. } \\
\text { (2020) [8] }\end{array}$ & $\begin{array}{l}\text { Effectiveness of } \\
\text { A Pilates } \\
\text { Training } \\
\text { Program on } \\
\text { Cognitive and } \\
\text { Functional } \\
\text { Abilities in } \\
\text { Postmenopausal } \\
\text { Women }\end{array}$ & $\begin{array}{l}110 \\
\text { MP } 55 \\
\text { C } 55 \\
\text { F }\end{array}$ & $\begin{array}{l}\text { To determine the } \\
\text { effects of a Pilates } \\
\text { exercises program } \\
\text { on the cognitive } \\
\text { and physical } \\
\text { functioning of } \\
\text { older Spanish } \\
\text { women. }\end{array}$ & $\begin{array}{l}\text { MP: } \\
\text { Pilates-based } \\
\text { matwork } \\
\text { C: } \\
\text { No intervention } \\
\text { Duration: } \\
12 \text { weeks } \\
2 x \text { week } \\
60^{\prime}\end{array}$ & $\begin{array}{l}\text { Global cognitive } \\
\text { function (Mini-Mental } \\
\text { State Examination), } \\
\text { verbal fluency } \\
\text { (Isaacs test), executive } \\
\text { function (Trail Making } \\
\text { Test), functional } \\
\text { flexibility (Back Scratch } \\
\text { Test and } \\
\text { Chair Sit-and-Reach } \\
\text { Test), and lower-body } \\
\text { strength (30 s } \\
\text { Chair-Stand Test) }\end{array}$ & $\begin{array}{l}\text { The main findings of this study } \\
\text { suggest that women in the MP } \\
\text { (within-group differences) } \\
\text { experienced improvements } \\
\text { across all the variables } \\
\text { examined } \\
\text { except for global cognitive } \\
\text { function. When compared with } \\
\text { the C (between-group } \\
\text { differences), our analysis } \\
\text { revealed significant benefits in } \\
\text { the MP for all measures except } \\
\text { for global cognitive function } \\
\text { and functional flexibility (Back } \\
\text { Scratch Test). }\end{array}$ & $\begin{array}{l}\text { The results suggest } \\
\text { that Pilates has the } \\
\text { potential to improve } \\
\text { both cognitive and } \\
\text { functional abilities } \\
\text { among Spanish } \\
\text { women aged } 60 \\
\text { years and over. }\end{array}$ & $8 / 10$ \\
\hline 26 & $\begin{array}{l}\text { Lima, M.; Silva, B.; } \\
\text { Rocha-Rodrigues, } \\
\text { S.; Bezerra, P. } \\
\text { (2021) [3] }\end{array}$ & $\begin{array}{l}\text { The impact of } \\
\text { an 8-week } \\
\text { Pilates-based } \\
\text { physical } \\
\text { training } \\
\text { program on } \\
\text { functional } \\
\text { mobility: data } \\
\text { from a } \\
\text { septuagenarian } \\
\text { group }\end{array}$ & $\begin{array}{l}20 \\
\text { MP } 10 \\
\text { C } 10 \\
M / F\end{array}$ & $\begin{array}{l}\text { Assess the effects } \\
\text { of a Pilates } \\
\text { program on } \\
\text { functional } \\
\text { mobility and } \\
\text { strength of elderly } \\
\text { in nursing homes. }\end{array}$ & $\begin{array}{l}\text { MP: Mat Pilates } \\
\text { C: No } \\
\text { intervention } \\
\text { Duration: } \\
8 \text { weeks } \\
\text { 2x week } \\
60^{\prime}\end{array}$ & $\begin{array}{l}\text { Anthropometric } \\
\text { measurements: Weight, } \\
\text { height, BMI, waist } \\
\text { perimeter, thigh } \\
\text { perimeter } \\
\text { Strength tests (upper } \\
\text { and lower limbs) } \\
6 \text { min walk test } \\
\text { Balance test (OLS with } \\
\text { open and closed eyes) } \\
\text { Functional Mobility } \\
\text { (TUG) }\end{array}$ & $\begin{array}{l}\text { MP obtained higher results for } \\
\text { lower limb strength }(p=0.013 ; \\
d=0.56) \text { and for the } 6 \text { min walk } \\
\text { test }(p=0.04 ; d=0.45) \text { when } \\
\text { compared to the Control Group } \\
\text { (C). MP also obtained better } \\
\text { results in the "OLS" and "TUG" } \\
\text { tests. Significant correlations } \\
\text { were found between strength } \\
\text { and cardiorespiratory fitness } \\
\text { ( } p<0.01, \mathrm{r}=0.62) \text {, between } \\
\text { cardiorespiratory fitness, and } \\
\text { "OLS", eyes closed and both } \\
\text { lower limbs }(p=0.04, \mathrm{r}=0.45 ; \\
p=0.05, \mathrm{r}=0.45), \text { respectively. }\end{array}$ & $\begin{array}{l}8 \text { weeks of Pilates } \\
\text { improved strength } \\
\text { and functional } \\
\text { mobility in elderly } \\
\text { people living in } \\
\text { nursing homes. }\end{array}$ & $6 / 10$ \\
\hline
\end{tabular}


Table 5. Cont.

\begin{tabular}{|c|c|c|c|c|c|c|c|c|c|}
\hline$n$ & Author & Title & $\begin{array}{l}\text { Subjects/ } \\
\text { Group }\end{array}$ & Objective & Intervention & Outcomes & Results & Conclusion(s) & $\begin{array}{c}\text { PEDro } \\
\text { Scale }\end{array}$ \\
\hline 27 & $\begin{array}{l}\text { Buttelli, A.K.; } \\
\text { Costa, R.R.; } \\
\text { Farinha, J.B.; } \\
\text { Fagundes, A.O.; } \\
\text { Vieira, A.F.; } \\
\text { Barroso, B.M.; } \\
\text { Bracht, C.G.; } \\
\text { Coconcelli, L.; } \\
\text { Reichert, T.; } \\
\text { Rocha, } \\
\text { V.B.; Kruel, L.M. } \\
\text { (2021) [46] }\end{array}$ & $\begin{array}{l}\text { Pilates training } \\
\text { improves } \\
\text { aerobic capacity, } \\
\text { but not lipid or } \\
\text { lipoprotein } \\
\text { levels in elderly } \\
\text { women with } \\
\text { dyslipidemia: A } \\
\text { controlled trial }\end{array}$ & $\begin{array}{l}26 \\
\text { MP } 20 \\
\text { C } 6\end{array}$ & $\begin{array}{l}\text { To verify the } \\
\text { effects of Pilates } \\
\text { training } \\
\text { on total } \\
\text { cholesterol (TC), } \\
\text { triglycerides (TG), } \\
\text { low-density } \\
\text { lipoprotein (LDL), } \\
\text { high-density } \\
\text { lipoprotein (HDL), } \\
\text { glucose, and } \\
\text { C-reactive protein } \\
\text { (CRP) levels, as } \\
\text { well as on } \\
\text { functionality of } \\
\text { postmenopausal } \\
\text { women with } \\
\text { dyslipidemia. }\end{array}$ & $\begin{array}{l}\text { MP: } \\
\text { Pilates-based } \\
\text { matwork } \\
\text { C: } \\
\text { No intervention } \\
\text { Duration: } \\
10 \text { weeks } \\
2 \text { to } 4 \times \text { week } \\
45 \text { to } 55^{\prime}\end{array}$ & $\begin{array}{l}\text { Biochemical analyses } \\
\text { and functionality } \\
\text { parameters } \\
\text { were measured before } \\
\text { and after the } 10 \text { weeks. }\end{array}$ & $\begin{array}{l}\text { No significant differences were } \\
\text { observed in TC, TG, LDL, and } \\
\text { HDL for both groups. Regarding } \\
\text { glucose and CRP levels, } \\
\text { significant reductions were } \\
\text { observed in both groups after the } \\
\text { intervention period. In } \\
\text { functional parameters, both } \\
\text { groups significantly increased } \\
\text { their } 30 \text { s chair stand } \\
\text { test values. On the other hand, } \\
\text { only the Pilates group presented } \\
\text { significant increments in the } \\
6 \text { min walk test }(p<0.05) \text {. }\end{array}$ & $\begin{array}{l}\text { Pilates training did } \\
\text { not change lipid or } \\
\text { lipoprotein levels, } \\
\text { but improved the } \\
\text { cardiorespiratory } \\
\text { fitness of elderly } \\
\text { women with } \\
\text { dyslipidemia, }\end{array}$ & $4 / 10$ \\
\hline 28 & $\begin{array}{l}\text { Dlugosz-Boś, M.; } \\
\text { Filar-Mierzwa, K.; } \\
\text { Stawarz, R.; } \\
\text { Ścislowska- } \\
\text { Czarnecka, A.; } \\
\text { Jankowicz- } \\
\text { Szymańska, A.; } \\
\text { Bac, A. (2021) [2] }\end{array}$ & $\begin{array}{l}\text { Effect of Three } \\
\text { Months Pilates } \\
\text { Training on } \\
\text { Balance and Fall } \\
\text { Risk in Older } \\
\text { Women }\end{array}$ & $\begin{array}{l}50 \\
\text { MP } 30 \\
\text { C } 20 \\
\text { F }\end{array}$ & $\begin{array}{l}\text { To assess the effect } \\
\text { of Pilates exercises } \\
\text { on balance and } \\
\text { fall risk in older } \\
\text { women. }\end{array}$ & $\begin{array}{l}\text { MP: } \\
\text { Pilates-based } \\
\text { matwork } \\
\text { C: } \\
\text { No intervention } \\
\text { Duration: } \\
12 \text { weeks } \\
2 x \text { week } \\
45^{\prime}\end{array}$ & $\begin{array}{l}\text { Timed } \\
\text { Up-and-Go (TUG) } \\
\text { OLST } \\
\text { Freestep } \\
\text { baropodometric } \\
\text { platform } \\
\text { and } \\
\text { Biosway platform }\end{array}$ & $\begin{array}{l}\text { After intervention, significantly } \\
\text { decreased values of the surface } \\
\text { of the ellipse ( } p=0.0037) \text { and } \\
\text { mean values of velocity } \\
(p=0.0262) \text { for the right } \\
\text { foot in the experimental group } \\
\text { were observed. The Limits of } \\
\text { Stability (LoS) test ( } p=0.005) \\
\text { and the Modified Clinical Test of } \\
\text { Sensory Interaction on Balance } \\
\text { (m-CTSIB) performed on an } \\
\text { unstable surface with eyes closed } \\
\text { ( } p=0.0409) \text { indicated statistically } \\
\text { significant changes in the } \\
\text { experimental group. }\end{array}$ & $\begin{array}{l}\text { Pilates } \\
\text { training affected the } \\
\text { participants' } \\
\text { balance by } \\
\text { improving LoS and } \\
\text { reducing fall risk. }\end{array}$ & $4 / 10$ \\
\hline
\end{tabular}


Table 5. Cont.

\begin{tabular}{|c|c|c|c|c|c|c|c|c|c|}
\hline$n$ & Author & Title & $\begin{array}{l}\text { Subjects/ } \\
\text { Group }\end{array}$ & Objective & Intervention & Outcomes & Results & Conclusion(s) & $\begin{array}{c}\text { PEDro } \\
\text { Scale }\end{array}$ \\
\hline 29 & $\begin{array}{l}\text { Patti, A.; Zangla, } \\
\text { D.; Sahin, F.N.; } \\
\text { Cataldi, S.; } \\
\text { Lavanco, G.; } \\
\text { Palma, A.; } \\
\text { Fischietti, F. (2021) } \\
\text { [47] }\end{array}$ & $\begin{array}{l}\text { Physical } \\
\text { exercise and } \\
\text { prevention of } \\
\text { falls. Effects } \\
\text { of a Pilates } \\
\text { training method } \\
\text { compared with } \\
\text { a } \\
\text { general physical } \\
\text { activity program } \\
\text { A randomized } \\
\text { controlled trial }\end{array}$ & $\begin{array}{l}41 \\
\text { MP } 18 \\
\text { PAG } 23 \\
\text { M/F }\end{array}$ & $\begin{array}{l}\text { To compare a } \\
\text { general physical } \\
\text { activity program } \\
\text { for the elderly } \\
\text { with a Pilates } \\
\text { program to } \\
\text { evaluate the } \\
\text { effects on balance } \\
\text { and on reducing } \\
\text { the risk of falling. }\end{array}$ & $\begin{array}{l}\text { MP: } \\
\text { Pilates-based } \\
\text { matwork } \\
\text { PAG: } \\
\text { Non-specific } \\
\text { program of } \\
\text { physical activity } \\
\text { Duration: } \\
13 \text { weeks } \\
3 x \text { week } \\
50^{\prime}\end{array}$ & $\begin{array}{l}\text { Handgrip test } \\
\text { Berg balance scale test } \\
\text { (BBS) } \\
\text { and posturographic } \\
\text { analysis }\end{array}$ & $\begin{array}{l}\text { Spearman correlation } \\
\text { coefficient showed correlations } \\
\text { between the following } \\
\text { parameters: BBS versus } \\
\text { handgrip test ( } \mathrm{r}=0.68) \text {; BBS } \\
\text { versus ellipse surface area } \\
(\mathrm{r}=0.75) \text {. There were } \\
\text { significant differences between } \\
\text { groups after the exercise } \\
\text { program: both groups showed } \\
\text { an improvement in } \\
\text { performance but the MP } \\
\text { recorded significantly better } \\
\text { results than the PAG. }\end{array}$ & $\begin{array}{l}\text { Physical activity } \\
\text { improves both } \\
\text { balance and } \\
\text { strength. However, } \\
\text { the data show that } \\
\text { Pilates has a greater } \\
\text { effect on these } \\
\text { physical abilities } \\
\text { than a general } \\
\text { physical activity } \\
\text { program. }\end{array}$ & $7 / 10$ \\
\hline 30 & $\begin{array}{l}\text { Pucci G.F.; Neves, } \\
\text { E.B.; Santana, F.S.; } \\
\text { Neves, D.A.; } \\
\text { Saavedra, F.F. } \\
\text { (2021) [5] }\end{array}$ & $\begin{array}{l}\text { Comparative } \\
\text { analysis of } \\
\text { pilates and } \\
\text { resistance } \\
\text { trianing in } \\
\text { physical fitness } \\
\text { of the elderly }\end{array}$ & $\begin{array}{l}25 \\
\text { MP } 7 \\
\text { TR } 6 \\
\text { GLC } 12 \\
\text { F }\end{array}$ & $\begin{array}{l}\text { Assess the effects } \\
\text { of two exercise } \\
\text { interventions } \\
\text { (resistance } \\
\text { training and } \\
\text { Pilates) in the } \\
\text { elderly. }\end{array}$ & $\begin{array}{l}\text { MP: } \\
\text { Mat Pilates } \\
\text { TR: Resistance } \\
\text { training } \\
\text { GLC: games, } \\
\text { memory } \\
\text { exercises, motor } \\
\text { coordination } \\
\text { exercises. } \\
\text { Duration: } \\
24 \text { Weeks } \\
2 x \text { Week } \\
60^{\prime}\end{array}$ & $\begin{array}{l}\text { Senior Fitness } \\
\text { Test-Test battery for } \\
\text { physical fitness in the } \\
\text { elderly (strength, } \\
\text { aerobic resistance, } \\
\text { flexibility, dynamic } \\
\text { balance, agility and } \\
\text { Body Mass Index) }\end{array}$ & $\begin{array}{l}\text { There was a significant increase } \\
\text { for the MP and TR groups in } \\
\text { the forearm flexion test pre- } \\
\text { and post-intervention. The TR } \\
\text { group also showed an } \\
\text { increasing the handgrip test, } \\
\text { particularly between week } 12 \\
\text { and } 24 \text {. }\end{array}$ & $\begin{array}{l}\text { Pilates and } \\
\text { resistance training } \\
\text { contributed to a } \\
\text { significant increase } \\
\text { in the strength of } \\
\text { elderly. }\end{array}$ & $5 / 10$ \\
\hline
\end{tabular}


Of the six studies presented in Table 1, half did not report advantages of the Pilates method per se or in combination with other techniques and interventions [22,27]. The first did not find any evident benefit for trunk strength and balance, whereas the second did not find Pilates to be the most effective method in strength gains or in the transfer of these gains to the functional autonomy of the elderly. In contrast, one study shows a beneficial effect of Pilates in the functional autonomy of the elderly [24]. The remaining studies showed gains in flexibility [23], emotional health [25], balance, and reduction in the risk of falling [26].

The study of Gabizon et al. [28] is the third without evidence of a positive influence of Pilates. To the authors, this may be due to the fact that Pilates is not a specific method for the development of balance. On the other hand, there is the advantage of Pilates in reducing waist perimeter and BMI [30]. In the remaining studies, balance and confidence in balance [32] and improvements in walking ability and in fear of falling, with the corresponding reduction in the risk of falling, were highlighted by some authors [29,31]. Lower limb strength and functional autonomy were also reported as having benefited from Pilates [33].

Regarding this set of studies, lower limb strength improvements were reported $[35,36,38]$. Balance is also improved with Pilates, particularly for those with deficits in trunk control and trunk stability [37]. Jurakic et al. (2017) showed that Pilates is beneficial for elderly people with short-term memory deficits [34]. Finally, pulmonary function also improves [39].

Balance improvements, reduction in the risk of falling, increase in functional mobility, and postural stability are reported in this set of studies [42,44]. Additionally, improvements in pulmonary function are also reported [43]. Improvements in quality of life, satisfaction with life, and perception of health status were also reported [40,41,45], as well as improvements in functional autonomy [40] and sleep quality [41].

The studies presented a set of results considering the advantages of Pilates in balance $[2,3,47]$ and strength $[3,5,47]$. One study revealed improvements in functional capacity, walking, and mobility [8]. The same authors also found beneficial effects of Pilates interventions in the cognitive dimension. Advantages in cardiorespiratory fitness were also reported [46].

In summary, 27 of the 30 studies analysed reported advantages of Pilates for the elderly. The areas where more advantages were reported were in static or dynamic balance $[3,5,33,35,36,38,39,43,47]$. Four studies showed benefits in total strength, three in lower limb strength, and two studies reported benefits in respiratory strength. Functional capacity and functional autonomy also tend to improve with Pilates, according to four studies $[8,33,40,42]$. The psychological and mental-health-related variables (e.g., perception of health, quality of life, satisfaction with life, emotional health, and sleep quality) also improved significantly with Pilates $[25,40,41,45]$. In two experimental studies, flexibility was improved [23,42], and two other studies showed improvement in aerobic resistance [38,46]. A decrease in BMI and waist perimeter was also reported [30]. Finally, gains in short-term memory were also reported in cognitively disabled people [34].

\subsection{Observational or Non-Randomized Studies}

Table 6 presents the details of the observational or non-randomized studies included in this review. 
Table 6. Structured summary of observational or non-randomized studies included in the review.

\begin{tabular}{|c|c|c|c|c|c|c|c|c|}
\hline$n$ & Author & Title & $\begin{array}{l}\text { Subjects/ } \\
\text { Group }\end{array}$ & Objective & Intervention & Outcomes & Results & Conclusion(s) \\
\hline 1 & $\begin{array}{l}\text { Queiroz, L.S.; } \\
\text { Bertolini, S.G.; } \\
\text { Benneman, R.M.; } \\
\text { Silva, E.S. (2016) [48] }\end{array}$ & $\begin{array}{l}\text { The effect Mat } \\
\text { Pilates practice on } \\
\text { muscle mass in } \\
\text { elderly women }\end{array}$ & $\begin{array}{l}\text { MPA } 43 \\
\text { F }\end{array}$ & $\begin{array}{l}\text { To verify that the } \\
\text { Mat Pilates } \\
\text { practice increases } \\
\text { muscle mass in } \\
\text { elderly women. }\end{array}$ & $\begin{array}{l}\text { MP: } \\
\text { Pilates Mat and } \\
\text { Apparatus } \\
\text { Duration: } \\
12 \text { weeks } \\
3 x \text { week } \\
40^{\prime}\end{array}$ & $\begin{array}{l}\text { Evaluation of arm } \\
\text { muscle area before } \\
\text { and after } \\
\text { intervention } \\
\text { Tricep skinfold }\end{array}$ & $\begin{array}{l}\text { Statistically significant } \\
\text { difference was observed } \\
(p<0.002) \text { between the } \\
\text { average value of the arm } \\
\text { muscle area, before } \\
\left(35.56 \mathrm{~cm}^{2}\right) \text { and after the } \\
\text { exercises. }\left(42.72 \mathrm{~cm}^{2}\right)\end{array}$ & $\begin{array}{l}\text { Mat Pilates program } \\
\text { generates positive } \\
\text { effect on increasing } \\
\text { the muscle mass of } \\
\text { the elderly. }\end{array}$ \\
\hline 3 & Roh, S.Y. (2016) [50] & $\begin{array}{l}\text { Effects of a } \\
\text { 12-week Pilates } \\
\text { exercise program } \\
\text { on wellness in } \\
\text { elderly }\end{array}$ & 88 & $\begin{array}{l}\text { Examine the } \\
\text { efficiency of a } \\
\text { 12-week Pilates } \\
\text { program for the } \\
\text { elderly. }\end{array}$ & $\begin{array}{l}\text { Mat Pilates } \\
\text { Duration: } \\
12 \text { weeks } \\
3 x \text { week } \\
50^{\prime}\end{array}$ & $\begin{array}{l}\text { Well-being } \\
\text { Questionnaire }\end{array}$ & $\begin{array}{l}\text { After } 12 \text { weeks of practice, } \\
\text { participants felt significant } \\
\text { improvements in the } \\
\text { various domains in the } \\
\text { questionnaire: physical, } \\
(\mathrm{t}=2762, p<0.01) \text {, social } \\
(\mathrm{t}=3362, p<0.001) \text {, } \\
\text { spiritual }(\mathrm{t}=2307, p<0.05) \text {, } \\
\text { and emotional well-being } \\
(\mathrm{t}=2489, p<0.05) \text {. }\end{array}$ & $\begin{array}{l}\text { Pilates helped } \\
\text { improve the } \\
\text { well-being of the } \\
\text { elderly. }\end{array}$ \\
\hline
\end{tabular}


Table 6. Cont.

\begin{tabular}{|c|c|c|c|c|c|c|c|c|}
\hline$n$ & Author & Title & $\begin{array}{l}\text { Subjects/ } \\
\text { Group }\end{array}$ & Objective & Intervention & Outcomes & Results & Conclusion(s) \\
\hline 4 & $\begin{array}{l}\text { Hwang, Y.; Park, J.; } \\
\text { and Lim, K. (2016) } \\
\text { [51] }\end{array}$ & $\begin{array}{l}\text { Effects of Pilates } \\
\text { Exercise on } \\
\text { Salivary Secretory } \\
\text { Immunoglobulin } \\
\text { A Levels in Older } \\
\text { Women }\end{array}$ & $\begin{array}{l}12 \\
\mathrm{MP} 6 \\
\mathrm{C} 6 \\
\mathrm{~F}\end{array}$ & $\begin{array}{l}\text { Examine the } \\
\text { effects of a Pilates } \\
\text { program on the } \\
\text { immune function } \\
\text { of older women. }\end{array}$ & $\begin{array}{l}\text { MP: } \\
\text { Pilates Matwork } \\
\text { C: } \\
\text { No workout } \\
\text { Duration: } \\
12 \text { weeks } \\
3 x \text { week } \\
50^{\prime}\end{array}$ & $\begin{array}{l}\text { Aerobic Power } \\
\text { (Astrand) } \\
\text { Salivary secretions } \\
\text { Questionnaire about } \\
\text { colds and } \\
\text { respiratory ilnessess }\end{array}$ & $\begin{array}{l}\text { Salivary flow was } \\
\text { significantly higher } \\
\text { in the MP than in the C. } \\
\text { After the acute } \\
\text { high-intensity exercises } \\
\text { were performed following } \\
\text { the three-month Pilates } \\
\text { exercise program, the } \\
\text { salivary flow rate was } \\
\text { significantly higher at all } \\
\text { time points. The S-IgA } \\
\text { secretion rate significantly } \\
\text { increased } 30 \text { min after acute } \\
\text { high-intensity } \\
\text { exercise performed } \\
\text { following the three-month } \\
\text { Pilates exercise program. }\end{array}$ & $\begin{array}{l}\text { Regular } \\
\text { participation in a } \\
\text { moderate-intensity } \\
\text { Pilates exercise } \\
\text { program can } \\
\text { increase salivary } \\
\text { flow rate and S-IgA } \\
\text { secretion in older } \\
\text { women. }\end{array}$ \\
\hline
\end{tabular}


Table 6. Cont.

\begin{tabular}{|c|c|c|c|c|c|c|c|c|}
\hline$n$ & Author & Title & $\begin{array}{l}\text { Subjects/ } \\
\text { Group }\end{array}$ & Objective & Intervention & Outcomes & Results & Conclusion(s) \\
\hline 6 & $\begin{array}{l}\text { Bertoli, J.; Pupo, J.; } \\
\text { Vaz, M.A.; Detanico, } \\
\text { D.; Biduski, G.M.; } \\
\text { Freitas, C.R. (2018) } \\
\text { [53] }\end{array}$ & $\begin{array}{l}\text { Effects of Mat } \\
\text { Pilates on hip and } \\
\text { knee isokinetic } \\
\text { torque parameters } \\
\text { in elderly women }\end{array}$ & $\begin{array}{l}\text { MP } 42 \\
\text { F }\end{array}$ & $\begin{array}{l}\text { Analyse the effects } \\
\text { of Mat Pilates on } \\
\text { the isokinetic } \\
\text { strength of the } \\
\text { lower limbs in } \\
\text { elderly women. }\end{array}$ & $\begin{array}{l}\text { MP: Mat Pilates } \\
\text { Duration: } \\
12 \text { weeks } \\
3 x \text { week } \\
60^{\prime}\end{array}$ & $\begin{array}{l}\text { Isokinetic } \\
\text { Dynamometer }\end{array}$ & $\begin{array}{l}\text { Mat Pilates produces } \\
\text { improvements in knee } \\
\text { flexors strength and in hip } \\
\text { flexors, and extersors } \\
\text { maximum strength } \\
\text { (6 weeks). Improvements in } \\
\text { maximum strength and } \\
\text { mechanical work of the } \\
\text { knee extensors and hip } \\
\text { flexors and extensors were } \\
\text { also verified after the } \\
\text { 12-week intervention. }\end{array}$ & $\begin{array}{l}\text { Pilates training } \\
\text { periodization } \\
\text { induces significant } \\
\text { improvements in } \\
\text { isokinetic strength. }\end{array}$ \\
\hline 7 & $\begin{array}{l}\text { Mello, N.F.; Costa, } \\
\text { D.L.; Vasconcellos, } \\
\text { S.V.; Lensen, C.M.; } \\
\text { Corazza, S.T. (2018) } \\
\text { [54] }\end{array}$ & $\begin{array}{l}\text { Contemporary } \\
\text { Pilates in physical } \\
\text { fitness, cognition } \\
\text { and quality of life } \\
\text { in the elderly }\end{array}$ & $\begin{array}{l}16 \\
\mathrm{MP} 8 \\
\mathrm{C} 8 \\
\mathrm{M} / \mathrm{F}\end{array}$ & $\begin{array}{l}\text { To evaluate the } \\
\text { effects of the } \\
\text { contemporary } \\
\text { Pilates method on } \\
\text { the physical } \\
\text { fitness, } \\
\text { cognition, and } \\
\text { quality of life of } \\
\text { the elderly. }\end{array}$ & $\begin{array}{l}\text { MP: } \\
\text { Pilates Matwork } \\
\text { C: } \\
\text { No intervention } \\
\text { Duration: } \\
15 \text { weeks } \\
2 x \text { week } \\
60^{\prime}\end{array}$ & $\begin{array}{l}\text { The Senior Fitness } \\
\text { Test battery (SFT), } \\
\text { the Vienna Test } \\
\text { System and the } \\
\text { EUROHIS QOL-8 } \\
\text { quality-of-life } \\
\text { questionnaire were } \\
\text { used. }\end{array}$ & $\begin{array}{l}\text { Significant difference } \\
(p<0.05) \text { was observed in } \\
\text { the variables: lower and } \\
\text { upper extremity flexibility } \\
\text { test }(p=0.007) \text {, agility } \\
(p=0.001) \text { and dynamic } \\
\text { balance }(p=0.001) \text {, aerobic } \\
\text { endurance test ( } p=0.001) \\
\text { and } \\
\text { Attention and concentration } \\
\text { test time }(p=0.047)\end{array}$ & $\begin{array}{l}\text { The contemporary } \\
\text { Pilates method } \\
\text { improves the health } \\
\text { of the elderly, } \\
\text { thereby helping to } \\
\text { promote quality of } \\
\text { life. }\end{array}$ \\
\hline 8 & $\begin{array}{l}\text { Scherf, B.G.; } \\
\text { Guadagnin, E.C.; } \\
\text { Tier, C.G.; De } \\
\text { Almeida Dias, S.L. } \\
\text { (2019) [55] }\end{array}$ & $\begin{array}{l}\text { Effect of a Mat } \\
\text { Pilates protocol on } \\
\text { fall risk in elderly } \\
\text { women. }\end{array}$ & $\begin{array}{l}\text { MP } 16 \\
\text { F }\end{array}$ & $\begin{array}{l}\text { To verify if } \\
\text { a short-term Mat } \\
\text { Pilates protocol is } \\
\text { effective in } \\
\text { reducing fall risk } \\
\text { in elderly women. }\end{array}$ & $\begin{array}{l}\text { MP: } \\
\text { Mat Pilates } \\
\text { Duration: } \\
5 \text { weeks } \\
2 x \text { week } \\
60^{\prime}\end{array}$ & $\begin{array}{l}\text { Sharp Romberg Test } \\
\text { Berg Balance Scale } \\
\text { (BBS) } \\
30 \text { s sit-to-stand } \\
\text { testTimed } \\
\text { Up-and-Go test } \\
\text { (TUG) } \\
\text { Gait Kinematic } \\
\text { assessment }\end{array}$ & $\begin{array}{l}\text { Significant improvements } \\
\text { in strength, static, and } \\
\text { dynamic balance, functional } \\
\text { mobility, gait speed, and } \\
\text { step length were verified. }\end{array}$ & $\begin{array}{l}\text { A short term Mat } \\
\text { Pilates protocol, } \\
\text { may be an efficient } \\
\text { alternative to reduce } \\
\text { fall risk in the } \\
\text { elderly population. }\end{array}$ \\
\hline
\end{tabular}


Table 6. Cont.

\begin{tabular}{|c|c|c|c|c|c|c|c|c|}
\hline$n$ & Author & Title & $\begin{array}{l}\text { Subjects/ } \\
\text { Group }\end{array}$ & Objective & Intervention & Outcomes & Results & Conclusion(s) \\
\hline 9 & $\begin{array}{l}\text { Bueno, J.A.; Alves, } \\
\text { R.G.; Smoralek, } \\
\text { A.C.; Junior, T.S. } \\
\text { (2019) [56] }\end{array}$ & $\begin{array}{l}\text { Haemodynamic } \\
\text { and perceptual } \\
\text { behaviour in } \\
\text { elderly women } \\
\text { subjected to one } \\
\text { session of different } \\
\text { Pilates protocols. }\end{array}$ & $\begin{array}{l}19 \\
\text { PA } 10 \\
\text { MP } 9 \\
\text { F }\end{array}$ & $\begin{array}{l}\text { Verify the } \\
\text { haemodynamic } \\
\text { behaviour and } \\
\text { compare the } \\
\text { physiological } \\
\text { response and } \\
\text { safety of two } \\
\text { Pilates protocols } \\
\text { (mat and } \\
\text { apparatus) in } \\
\text { elderly women. }\end{array}$ & $\begin{array}{l}\text { PA: Pilates } \\
\text { Apparatus } \\
\text { MP: Mat Pilates }\end{array}$ & $\begin{array}{l}\text { Heart Rate (HR) } \\
\text { Blood Pressure (BP) } \\
\text { Perceived Exhersion } \\
\text { (PE) } \\
\text { Double product, } \\
\text { calculated as } \\
\text { follows: } \\
\text { HR.mmHg.bpm } \\
\text { Scale of Perceived } \\
\text { Exhertion } \\
\text { (OMNI-RES) }\end{array}$ & $\begin{array}{l}\text { Diastolic pressure during } \\
\text { recovery after } 60 \mathrm{~min} \\
\text { increased } 10 \mathrm{bpm}(p<0.04) \text {, } \\
\text { as well as lower HR for the } \\
\text { PA during recovery HR } \\
(10 \mathrm{~min})(p<0.03) \text { and } \\
\text { post-recovery ( } 30 \text { min) } \\
(p<0.03) \text {. For both groups, } \\
\text { the results of the acute } \\
\text { session did not show } \\
\text { abnormalities in the double } \\
\text { product, with minimum PA } \\
\text { and MP values of } 9.820 \text { and } \\
8.740 \text { mmHg.bpm and } \\
\text { maximum values of } 13.824 \\
\text { and } 11.771 \text { mmHg.bpm, } \\
\text { respectively. The average } \\
\text { was very close between } \\
\text { both groups: PA } 11.416 \text { and } \\
\text { MP } 10.105 \text { mmHg.bpm, } \\
\text { respectively. }\end{array}$ & $\begin{array}{l}\text { Both protocols } \\
\text { appear to be safe } \\
\text { and efficient for } \\
\text { normotensive } \\
\text { elderly women. }\end{array}$ \\
\hline
\end{tabular}


Table 6. Cont.

\begin{tabular}{|c|c|c|c|c|c|c|c|c|}
\hline$n$ & Author & Title & $\begin{array}{l}\text { Subjects/ } \\
\text { Group }\end{array}$ & Objective & Intervention & Outcomes & Results & Conclusion(s) \\
\hline 10 & $\begin{array}{l}\text { Nascimento, M.M.; } \\
\text { Pereira, L.D.; Júnior, } \\
\text { E.C.; Castro, H.G.; } \\
\text { Appell, H.J. (2019) [57] }\end{array}$ & $\begin{array}{l}\text { Assess the } \\
\text { exteroceptive and } \\
\text { interoceptive } \\
\text { regulation of body } \\
\text { balance in active } \\
\text { elderly women }\end{array}$ & $\begin{array}{l}32 \\
\text { MP1 } 8 \\
\text { MP2 } 8 \\
\text { MP3 } 8 \\
\text { MP4 } 8 \\
\text { F }\end{array}$ & $\begin{array}{l}\text { To evaluate the } \\
\text { balance } \\
\text { performance of a } \\
\text { group of } \\
\text { physically active } \\
\text { elderly women, } \\
\text { with emphasis on } \\
\text { the regulation of } \\
\text { the visual, } \\
\text { vestibular, and } \\
\text { somatosensory } \\
\text { systems of the } \\
\text { static and dynamic } \\
\text { balance, as } \\
\text { well as their } \\
\text { performance in } \\
\text { gait tests and } \\
\text { flexibility. }\end{array}$ & $\begin{array}{l}\text { MP1: } \\
\text { Pilates matwork } \\
\text { (60-64 years old) } \\
\text { MP2: } \\
\text { Pilates matwork } \\
\text { (65-69 years old) } \\
\text { MP3: } \\
\text { Pilates matwork } \\
\text { (70-74 years old) } \\
\text { MP4: } \\
\text { Pilates matwork } \\
\text { (75-79 years old) } \\
\text { Duration: } \\
\text { 2x week } \\
60^{\prime}\end{array}$ & $\begin{array}{l}\text { Berg Balance Scale } \\
\text { (BBS) } \\
\text { Timed Up-and-Go } \\
\text { Test (TUG) } \\
\text { Functional Reach } \\
\text { Test (TAF), and } \\
\text { Body } \\
\text { Balance Test (TEC) }\end{array}$ & $\begin{array}{l}\text { BBS attained a conserved } \\
\text { equilibrium }[\mathrm{F}(3.29)=1.766, \\
p \geq 0.50], \text { the TUG for } \\
\text { preserved functional } \\
\text { independence } \\
{[\mathrm{F}(3.29)=0.418 ; p \geq 0.50] \text {, }} \\
\text { and TAF without risk of } \\
\text { falls. } \\
{[\mathrm{F}(3,20)=2228 ; p \geq 0.50] \text {. }} \\
\text { The TEC identified deficit of } \\
\text { interoceptive regulation of } \\
\text { balance for all ages and } \\
\text { compromise of } \\
\text { interoceptive regulation of } \\
\text { dynamic balance for } \\
\text { septuagenarians } \\
{[\mathrm{F}(3,29)=0.301 ; p \geq 0.50] \text {. }} \\
\text { A moderate correlation was } \\
\text { observed between } \mathrm{BBS}-\mathrm{TEC} \\
(\mathrm{r}=0.416, p=0.018), \\
\mathrm{TEC}-\mathrm{TUG}(\mathrm{r}=-345, \\
p=0.013) \text { and negative } \\
\text { between BBS-TUG } \\
(\mathrm{r}=-0.427, p=0.013) \text {. The } \\
\mathrm{TAF} \text { did not prove to be } \\
\text { equivalent to the other } \\
\text { instruments. }\end{array}$ & $\begin{array}{l}\text { Sexagenarian and } \\
\text { septuagenarian } \\
\text { women, regular } \\
\text { physical exercise } \\
\text { practitioners, } \\
\text { despite indicating } \\
\text { good performance } \\
\text { in tests of balance, } \\
\text { gait and flexibility, } \\
\text { presented } \\
\text { impairment of the } \\
\text { systems of sensorial } \\
\text { regulation of the } \\
\text { static and dynamic } \\
\text { balance }\end{array}$ \\
\hline
\end{tabular}


Table 6. Cont.

\begin{tabular}{|c|c|c|c|c|c|c|c|c|}
\hline$n$ & Author & Title & $\begin{array}{l}\text { Subjects/ } \\
\text { Group }\end{array}$ & Objective & Intervention & Outcomes & Results & Conclusion(s) \\
\hline 11 & $\begin{array}{l}\text { Machado, O.S.; } \\
\text { Campos, S.P.; Killian, } \\
\text { L.F.; Machado, G.C.; } \\
\text { Gianolla, F. (2020) [58] }\end{array}$ & $\begin{array}{l}\text { Effect of a single } \\
\text { exercise session on } \\
\text { blood glucose and } \\
\text { blood pressure in } \\
\text { elderly }\end{array}$ & $\begin{array}{l}30 \\
\text { AE } 6 \\
\text { RT } 6 \\
\text { F } 6 \\
\text { MP } 6 \\
\text { C } 6 \\
\text { M/F }\end{array}$ & $\begin{array}{l}\text { To analyse the } \\
\text { acute effect of } \\
\text { exercise on } \\
\text { post-exercise } \\
\text { hypotension (PEH) } \\
\text { and blood glucose } \\
\text { in the elderly. }\end{array}$ & $\begin{array}{l}\text { AE (Aquatic } \\
\text { Exercise) } \\
\text { RT (Resist. } \\
\text { Training) } \\
\text { F (Functional/ } \\
\text { Weight-bearing } \\
\text { Training) } \\
\text { MP (Pilates) } \\
\text { C (No } \\
\text { intervention) } \\
\text { Duration: } \\
26 \text { weeks } \\
3 \times \text { week } \\
60^{\prime}\end{array}$ & $\begin{array}{l}\text { Blood glucose was } \\
\text { recorded } 15 \text { min } \\
\text { before the } \\
\text { beginning of the } \\
\text { exercise session } \\
\text { and } 30 \text { min after } \\
\text { the end of it }\end{array}$ & $\begin{array}{l}\text { RT (systolic PEH and blood } \\
\text { glucose) and } \\
\text { the AE (diastolic PEH) were } \\
\text { able to promote the most } \\
\text { significant reductions when } \\
\text { compared to other } \\
\text { modalities. }\end{array}$ & $\begin{array}{l}\mathrm{RT} \text { and AE were } \\
\text { preferentially } \\
\text { recommended for } \\
\text { the elderly } \\
\text { population with } \\
\text { characteristics close } \\
\text { to the sample used } \\
\text { in } \\
\text { this research. }\end{array}$ \\
\hline 12 & $\begin{array}{l}\text { Choi, W.; Joo, Y.; Lee, } \\
\text { S. (2021) [59] }\end{array}$ & $\begin{array}{l}\text { Pilates exercise } \\
\text { focused on ankle } \\
\text { movements for } \\
\text { improving gait } \\
\text { ability in older } \\
\text { women }\end{array}$ & $\begin{array}{l}\text { MP } 22 \\
\text { F }\end{array}$ & $\begin{array}{l}\text { To determine } \\
\text { whether Pilates } \\
\text { exercise can } \\
\text { improve gait, } \\
\text { muscle strength, } \\
\text { and mobility in } \\
\text { community- } \\
\text { dwelling older } \\
\text { women }\end{array}$ & $\begin{array}{l}\text { MP: } \\
\text { Pilates matwork }\end{array}$ & $\begin{array}{l}\text { Weight } \\
\text { BMI } \\
\text { Skeletal Muscle } \\
\text { Mass } \\
\text { Body Fat } \\
\text { Percentage } \\
\text { Waist-Hip ratio } \\
\text { Gait: Speed } \\
\text { Cadence } \\
\text { Step length } \\
\text { Stride length } \\
\text { Bilateral Handgrip } \\
\text { Strength } \\
\text { 30 s chair } \\
\text { sit-to-stand test } \\
\text { Abdominal } \\
\text { Strength } \\
\text { Manual Muscle } \\
\text { test of ankle } \\
\text { dorsiflexors and } \\
\text { plantar flexors }\end{array}$ & $\begin{array}{l}\text { Significant improvements } \\
\text { were observed in the spatial } \\
\text { gait parameters, muscle } \\
\text { strength, and range of } \\
\text { motion of ankle }(p<0.05) \text {. }\end{array}$ & $\begin{array}{l}\text { Pilates exercise is } \\
\text { beneficial exercise to } \\
\text { improve gait, } \\
\text { muscle strength, } \\
\text { and mobility in } \\
\text { community- } \\
\text { dwelling older } \\
\text { women. }\end{array}$ \\
\hline
\end{tabular}


Table 6. Cont.

\begin{tabular}{|c|c|c|c|c|c|c|c|c|}
\hline$n$ & Author & Title & $\begin{array}{l}\text { Subjects/ } \\
\text { Group }\end{array}$ & Objective & Intervention & Outcomes & Results & Conclusion(s) \\
\hline 13 & $\begin{array}{l}\text { Villarreal-Angeles, } \\
\text { M.A.; } \\
\text { Moncada-Jiménez, J; } \\
\text { Ruiz-Juan, F. (2021) } \\
\text { [9] }\end{array}$ & $\begin{array}{l}\text { Improvement of } \\
\text { psychological } \\
\text { variables through } \\
\text { Pilates in the } \\
\text { elderly }\end{array}$ & $\begin{array}{l}20 \\
\text { MP } 10 \\
\text { C } 10 \\
\text { F }\end{array}$ & $\begin{array}{l}\text { Determine the } \\
\text { effect of a Pilates } \\
\text { program on } \\
\text { psychological } \\
\text { variables in the } \\
\text { elderly. }\end{array}$ & $\begin{array}{l}\text { MP: } \\
\text { Mat Pilates } \\
\text { C: } \\
\text { No intervention } \\
\text { Duration: } \\
12 \text { Weeks } \\
\text { 3x week } \\
50^{\prime}\end{array}$ & $\begin{array}{l}\text { WHOQOL-100 } \\
\text { Questionnaire }\end{array}$ & $\begin{array}{l}\text { A significant interaction } \\
(p<0.05) \text { between pre- and } \\
\text { post-intervention, and } \\
\text { between groups (MP e C) } \\
\text { was verified in the } \\
\text { following dimensions: } \\
\text { physical health, social } \\
\text { relationships, and } \\
\text { psychological aspects. }\end{array}$ & $\begin{array}{l}\text { A 12-week Pilates } \\
\text { training program } \\
\text { allows the } \\
\text { improvement of } \\
\text { psychological } \\
\text { variables relevant } \\
\text { for the elderly } \\
\text { person's good } \\
\text { health. }\end{array}$ \\
\hline 14 & $\begin{array}{l}\text { Mueller, D.; Redkva, } \\
\text { P.E.; Borba, E.F.; } \\
\text { Barbosa, S.C.; } \\
\text { Krause, M.P.; Silva, } \\
\text { S.G. (2021) [60] }\end{array}$ & $\begin{array}{l}\text { Effect of Mat vs. } \\
\text { apparatus pilates } \\
\text { training on the } \\
\text { functional capacity } \\
\text { of elderly women }\end{array}$ & $\begin{array}{l}48 \\
\text { PA } 15 \\
\text { MP } 16 \\
\text { C } 17 \\
\text { F }\end{array}$ & $\begin{array}{l}\text { Compare mat } \\
\text { Pilates and } \\
\text { apparatus Pilates } \\
\text { on the functional } \\
\text { capacilty of } \\
\text { elderly women. }\end{array}$ & $\begin{array}{l}\text { PA: Apparatus } \\
\text { Pilates } \\
\text { MP: Mat Pilates } \\
\text { C:No Pilates } \\
\text { Duration: } \\
8 \text { Weeks } \\
2 x \text { week } \\
50^{\prime}\end{array}$ & $\begin{array}{l}\text { Senior Fitness Tests } \\
\text { (SFT) }\end{array}$ & $\begin{array}{l}\text { Both Pilates interventions } \\
\text { obtained improvements in } \\
\text { strength and flexibility of } \\
\text { lower and upper limbs, as } \\
\text { well as aerobic fitness and } \\
\text { agility. }\end{array}$ & $\begin{array}{l}\text { Apparatus and mat } \\
\text { Pilates offer similar } \\
\text { significant } \\
\text { improvements in the } \\
\text { functional capacity } \\
\text { of elderly women. }\end{array}$ \\
\hline
\end{tabular}


This section included 14 studies with similar benefits being reported, despite different methodologies used. Two studies show that Pilates is not the most effective intervention to control blood pressure, glycaemia [57], and the sensory regulation of static or dynamic balance [58]. The remaining studies, however, report gains in strength $[48,53,59]$ and improvements in the functional capacity and mobility of the elderly [52,59,60]. Psychological variables, such as self-resilience [49], well-being [50], quality of life [54], or health-related psychological variables [9], benefited with Pilates interventions. Additionally, improvements in walking ability [59], haemodynamic behaviour [56], fall-risk reduction [55], and salivary S-IgA [51] were mentioned once.

\section{Meta-Analysis}

\subsection{Balance}

Static balance (One Leg Stance-OLS) was analysed in three studies [2,3,26] and dynamic balance gathered nine, divided between the Timed Up-and-Go Test (TUG) $[2,3,26,29,38,42]$ and the Berg Balance Scale (BBS) $[28,42,47]$, with a total sample of 196 individuals.

The results of the meta-analysis calculated for the OLS show a mean difference of $3.33 \mathrm{~s}$ between groups, without statistical significance (95\% CI: $\left.[-0.27,6.94] ; I^{2}: 0 \%\right)$ (Figure 2).

\begin{tabular}{|c|c|c|c|c|c|c|c|c|c|c|}
\hline \multirow[b]{2}{*}{ Study or Subgroup } & \multicolumn{3}{|c|}{ Pilates } & \multicolumn{3}{|c|}{ Control } & \multicolumn{3}{|c|}{ Mean Difference } & \multirow{2}{*}{$\begin{array}{l}\text { Mean Difference } \\
\text { IV, Random, } 95 \% \mathrm{Cl}\end{array}$} \\
\hline & Mean & SD & Total & Mean & SD & Total & Weight & IV, Random, $95 \% \mathrm{Cl}$ & Year & \\
\hline Barker 2016 & 19.16 & 12.19 & 20 & 14.68 & 11.57 & 29 & $28.1 \%$ & $4.48[-2.32,11.28]$ & 2016 & \\
\hline Lima 2021 & 11.9 & 10.4 & 10 & 7.9 & 4.5 & 10 & $26.4 \%$ & $4.00[-3.02,11.02]$ & 2021 & \\
\hline Total $(95 \% \mathrm{Cl})$ & & & 60 & & & 59 & $100.0 \%$ & $3.33[-0.27,6.94]$ & & \\
\hline \multicolumn{10}{|c|}{$\begin{array}{l}\text { Heterogeneity: } \text { Tau }^{2}=0.00 ; \mathrm{Chi}^{2}=0.30, \mathrm{df}=2(\mathrm{P}=0.86) ;\left.\right|^{2}=0 \% \\
\text { Test for overall effect: } Z=1.81(P=0.07)\end{array}$} & $\begin{array}{ccccc}1 & 1 & 1 & 1 & 1 \\
-20 & -10 & 0 & 10 & 20 \\
\text { Favours [Control] } & \text { Favours [Pilates }\end{array}$ \\
\hline
\end{tabular}

Figure 2. Meta-analysis of the comparison of intervention and control groups on OLS Test.

For the dynamic balance, when considering each test separately, we found a significant mean difference favouring the Pilates group compared to the control group of $-0.60 \mathrm{~s}(95 \%$ CI: $[-0.70,-0.49] ; I^{2}: 0 \%$ ) in the TUG test. In the Berg Balance Scale (BBS) the results are not significant, despite the mean difference between groups also showing a better performance in the Pilates group (-1.46; 95\% CI: [-3.06, 0.15]; $I^{2}$ : 33\%).

For the global analysis of dynamic balance capacity, a significant difference in the mean difference was found between the Pilates and the control groups, with a value of -0.60 s (95\% CI: $[-0.71,-0.50] ; I^{2}: 0 \%$ ) with an advantage for the first group (Figure 3 ).

The three studies that assessed confidence in balance using the ABC Scale $[8,29,42]$ point to the absence of a significant mean difference between the groups $(3.65 ; 95 \% \mathrm{CI}$ : $[-1.50,8.79] ; I^{2}: 0 \%$ ) (Figure 4). 


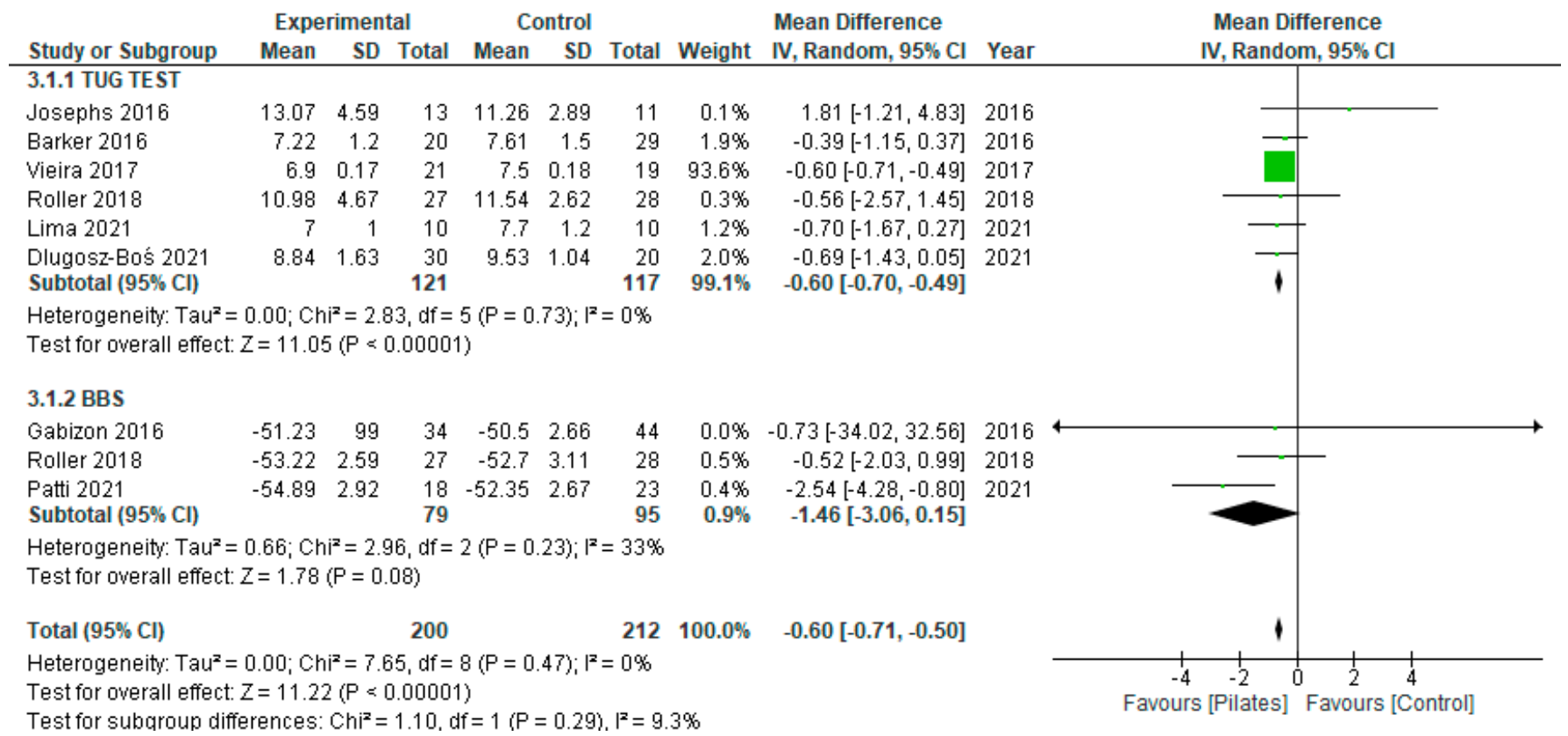

Figure 3. Meta-analysis of the comparison of intervention and control groups on dynamic balance.

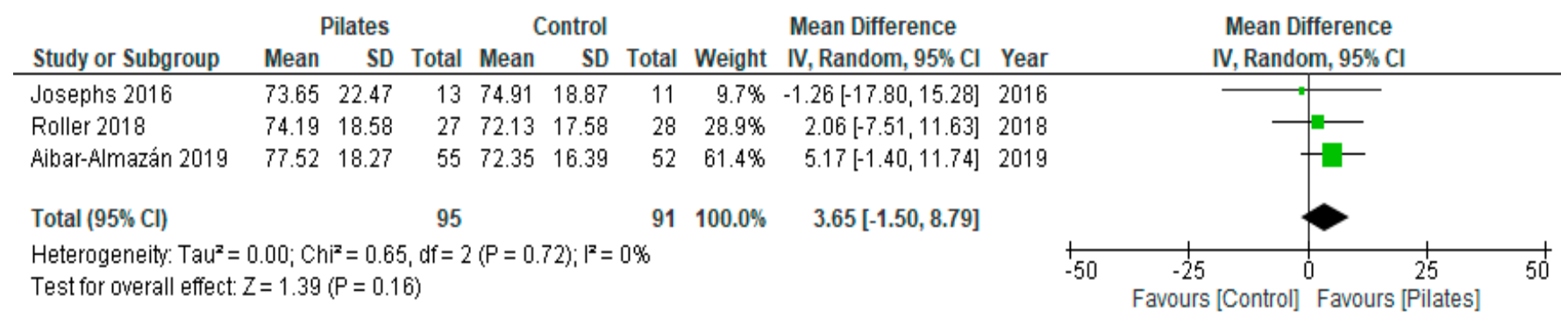

Figure 4. Meta-analysis of the comparison of intervention and control groups on $\mathrm{ABC}$ test.

\subsection{Strength}

Regarding strength, three studies using handgrip strength were eligible [3,5,47]. The mean difference between both groups is not significant $\left(1.86 ; 95 \%\right.$ CI: $\left.[-1.52,5.24] ; I^{2}: 0 \%\right)$ (Figure 5).

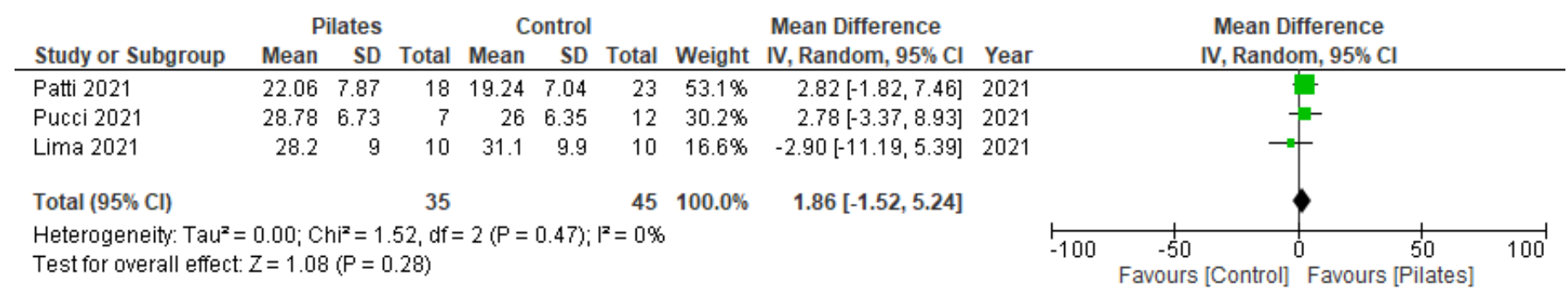

Figure 5. Meta-analysis of the comparison of intervention and control groups on handgrip test.

\subsection{Aerobic Capacity and Aerobic Resistance}

The 6 min walk test allows the assessment of aerobic capacity and aerobic resistance. From the studies analysed $[3,5,24,27]$, statistically significant differences were found in the mean difference to complete the test: $38,29 \mathrm{~m}$ plus to the Pilates group (95\% CI: [6.82, 69.77]; $I^{2}: 0 \%$ ). The data from Lima et al., 2021, were not included in the meta-analysis due to their heterogeneity (Figure 6). 


\begin{tabular}{|c|c|c|c|c|c|c|c|c|c|c|c|}
\hline \multirow[b]{2}{*}{ Study or Subgroup } & \multicolumn{3}{|c|}{ Pilates } & \multicolumn{3}{|c|}{ Control } & \multicolumn{3}{|c|}{ Mean Difference } & \multirow{2}{*}{\multicolumn{2}{|c|}{$\begin{array}{c}\text { Mean Difference } \\
\text { IV, Random, } 95 \% \mathrm{CI}\end{array}$}} \\
\hline & Mean & SD & Total & Mean & SD & Total & Weight & IV, Random, $95 \% \mathrm{CI}$ & Year & & \\
\hline Filho 2016 & 491.01 & 98.55 & 21 & 470.14 & 91.13 & 24 & $31.9 \%$ & $20.87[-34.86,76.60]$ & 2016 & \begin{tabular}{l|l}
-1 \\
-
\end{tabular} & \\
\hline Oliveira 2016 & 487.5 & 49.74 & 12 & 462.5 & 78.29 & 12 & $36.0 \%$ & $25.00[-27.48,77.48]$ & 2016 & & \\
\hline Pucci 2021 & 527.14 & 46.8 & 7 & 456.67 & 76.67 & 12 & $32.1 \%$ & $70.47[14.94,126.00]$ & 2021 & & \\
\hline Total $(95 \% \mathrm{Cl})$ & & & 40 & & & 48 & $100.0 \%$ & $38.29[6.82,69.77]$ & & & \\
\hline \multicolumn{10}{|c|}{$\begin{array}{l}\text { Heterogeneity: } \mathrm{Tau}^{2}=0.00 ; \mathrm{Chi}^{2}=1.91, \mathrm{df}=2(\mathrm{P}=0.38) ; \mathrm{I}^{2}=0 \% \\
\text { Test for overall effect: } Z=2.38(P=0.02)\end{array}$} & $\begin{array}{cccc}-200 & -100 & 0 & 100 \\
\text { Favours } & \text { [Control] } & \text { Favours [P }\end{array}$ & $\begin{array}{c}200 \\
\text { Pilates] }\end{array}$ \\
\hline
\end{tabular}

Figure 6. Meta-analysis of the comparison of intervention and control groups on $6 \mathrm{~m}$ walk test.

\section{Discussion}

The aim of this systematic revision is to collect and summarize the benefits of Pilates in the elderly population, within the current scientific production, assessing its contribution to Healthy Ageing (HA). In the first place, due to the state of the art and our findings, we could verify that the Pilates method has gained adepts over the last years. The increase in the elderly population is a fact and with it is the need to find processes that enable HA. Therefore, it is important to confirm the benefits of Pilates and scientifically validate them. The multiplication of the adaptations of this method, according to the current know-how or in order to meet the goals of the practice, has diversified the exercises and the reach of this method. A great example of this is the use of Pilates apparatuses that appear to point to differences between mat and apparatuses [61,62].

The use of springs and the consequent external load that they impose, along with the number of exercises made in an orthostatic position in these apparatuses may influence the results obtained. Similarly, the systematization difficulties and lack of consensus around the techniques and assessment instruments for the physical capabilities, among others, has resulted in a variability that creates difficulties in extrapolating and comparing the results and conclusions [63].

The results appear to show a robust tendency towards the benefits of Pilates for the elderly population. The analysis also points to a total absence of risks or contraindications of this method. Additionally, the benefits of this method are reinforced by the broad cultural and ethnic scope of the studies analysed, reducing any eventual contextual influence in the benefits presented.

Nevertheless, it is not clear that the Pilates method alone or in combination with other techniques and interventions [22,27] points to a robust tendency of the benefits of Pilates for the elder population. Still, it is important to emphasise the benefits of Pilates in the functional autonomy of the elderly [24], namely in flexibility [23], emotional health [25], and reduction in the risk of falling [26]. Moreover, there is an advantage of Pilates in reducing waist perimeter and BMI [30] and in improvements in walking ability [29,31,32]. Furthermore, the results also indicate that lower limb strength and functional autonomy were also reported as having benefited from Pilates [33].

Similarly, Jurakic et al. (2017) consider that Pilates has benefits for the elderly with short-term memory deficits [34] and that pulmonary function also improves [39]. In this context, improvements in quality of life, satisfaction with life, and perception of health status were also reported [40,41,45], as well as improvements in functional autonomy [40] and sleep quality [41]. Additionally, the results also showed the advantages of Pilates in balance $[2,3,47]$, strength $[3,5,47]$, improvements in functional capacity, walking and mobility [8], and in the cognitive dimension and cardiorespiratory function [46].

In a broader perspective, we emphasise that 27 of the 30 studies analysed reported the advantages of Pilates for the elderly. Standing out are the advantages in total strength, lower limb strength, functional capacity and functional autonomy [8,33,40,42]. Verified too are significant gains in psychological and mental health-related variables, in particular: perception of health, quality of life, satisfaction with life, emotional health $[25,40,41,45]$, flexibility [23,42], aerobic resistance [38,46], waist perimeter [30]. Finally, advantages were also found for people with cognitive impairment [34]. 
Although the results point out that Pilates is not the most effective intervention to control blood pressure, glycaemia [57], and the sensory regulation of static or dynamic balance [58], we could not, however, fail to highlight the positive effects of Pilates on strength $[48,53,59]$, improvements in the functional capacity and mobility of the elderly $[52,59,60]$, and in psychological variables such as self-resilience [49] and wellbeing [50]. Furthermore, improvements in haemodynamic behaviour [56] and salivary S-IgA [51] were also mentioned in the systematic review of the studies.

Moreover, the meta-analysis shows some results that are consistent with the previous systematic reviews and meta-analysis regarding the benefits of Pilates for the elderly $[10,15,16,63]$. All the demonstrated advantages of this practice for the development of static and dynamic balance show some consistency and robustness in the results. Regarding aerobic capacity and resistance, the results are consistent with the meta-analysis of Bueno et al. (2018).

The main limitations of this review were the time limitation and the exclusion of information regarding other studies (e.g., books, magazines, or theses). Regarding the studies included in our analysis, the limitations are related to the clinical and methodological variability. Additionally, the high number of studies in which the control group did not suffer any type of intervention may condition the results, namely when calculating a more robust meta-analysis. Most of the studies had a sample composed mainly of women, which may also limit the analysis and interpretation of the results. Therefore, it is important to increase the research in this field, particularly with greater and more gender-balanced samples. Moreover, the protocols should be more standardized in order to better compare the results obtained. Future studies should focus on the analysis of the relationship between the cost and benefit of a Pilates intervention in the elderly population, to better understand how health costs can be minimized and to contribute to a multidisciplinary and generalized HA. Moreover, future systematic reviews may analyse which type of psychomotor responses are associated with the eventual neuromuscular benefits that may come from a Pilates intervention in the elderly population.

\section{Conclusions}

This review of studies shows a robust tendency towards the benefits of Pilates in physical capacity and in dynamic balance. The results also show that Pilates may be beneficial for the health of the elderly, contributing to HA that may slow down and fight the degenerative processes associated with senescence. It is also concluded that the efficacy of Pilates has been studied in various areas of $\mathrm{HA}$ and has proven to be affordable and safe for the majority of people, using just a mat on the floor. This way, clinicians, therapists, and exercise professionals that work with the elderly population may find in Pilates a viable strategy towards healthy ageing. The well-being improvements in the elderly are enabled by an association between the social and the physical components of practising Pilates, thus contributing to a healthier and more active ageing.

Author Contributions: Conceptualization, M.J.P., R.S.M., and G.D.; methodology, M.J.P., R.S.M. and G.D. validation, M.J.P., R.M., R.S.M. and M.A.C.; data collection: M.J.P., R.M., R.S.M. and M.A.C.; statistical analyses and graphics: M.J.P., R.S.M., F.M. and G.D.; Writing the manuscript: M.J.P., R.S.M., R.G., J.G. and G.D.; Edited the final version: M.J.P. and G.D. All authors have read and agreed to the published version of the manuscript.

Funding: This work is funded by FCT/MCTES through national funds and when applicable cofunded EU funds under the project UIDB/50008/2020.

Institutional Review Board Statement: The study was conducted according to the guidelines of the Declaration of Helsinki and approved by the Ethics Committee of Polytechnic Institute of Coimbra (Approval number: 82_CEPC2/2021).

Informed Consent Statement: Not applicable. 
Data Availability Statement: The data presented in this study are available on request by the corresponding author.

Acknowledgments: Researcher MAC acknowledges the sponsor of FCT-Fundação para a Ciência e a Tecnologia, under the project UIDB/00285/2020.

Conflicts of Interest: The authors declare no conflict of interest.

\section{References}

1. World Health Organization. Resumo Relatório Mundial de Envelhecimento e Saúde. Available online: https:/ /apps.who.int/ iris/bitstream/handle/10665/186468/WHO_FWC_ALC_15.01_por.pdf?sequence=6 (accessed on 27 December 2021).

2. Długosz-Boś, M.; Filar-Mierzwa, K.; Stawarz, R.; Ścisłowska-Czarnecka, A.; Jankowicz-Szymańska, A.; Bac, A. Effect of three months pilates training on balance and fall risk in older women. Int. J. Environ. Res. Public Health 2021, 18, 3663. [CrossRef] [PubMed]

3. Lima, M.; Silva, B.; Rocha-Rodrigues, S.; Bezerra, P. The impact of an 8-week Pilates-based physical training program on functional mobility: Data from a septuagenarian group. Biomed. Hum. Kinet. 2021, 13, 11-19. [CrossRef]

4. Chodzko-Zajko, W.; Schwingel, A.; Park, C.H. Successful Aging: The role of physical activity. Am. J. Lifestyle Med. 2009, 3, 20-28. [CrossRef]

5. $\quad$ Pucci, G.C.; Neves, E.B.; Santana, F.S.; de Almeida Neves, D.; Saavedra, F.J. Comparative analysis of Pilates and resistance training in physical fitness of elderly. Retos 2021, 41, 628-637. [CrossRef]

6. Parra-Rizo, M.A. Componentes de influencia más valorados en la calidad de vida por las personas mayores de 60 años físicamente activas. Eur. J. Investig. Health Psychol. Educ. 2018, 7, 135-144. [CrossRef]

7. Wells, C.; Kolt, G.S.; Bialocerkowski, A. Defining Pilates exercise: A systematic review. Complement. Ther. Med. 2012, 20, 253-262. [CrossRef] [PubMed]

8. García-Garro, P.A.; Hita-Contreras, F.; Martínez-Amat, A.; Achalandabaso-Ochoa, A.; Jiménez-García, J.D.; Cruz-Díaz, D.; Aibar-Almazán, A. Effectiveness of a Pilates training program on cognitive and functional abilities in postmenopausal women. Int. J. Environ. Res. Public Health 2020, 17, 3580. [CrossRef]

9. Villarreal-Angeles, M.A.; Moncada-Jimenez, J.; Ruiz-Juan, F. Mejora de variables psicológicas en adultos mayores mediante Pilates. Retos 2020, 40, 47-52. [CrossRef]

10. Moreno-Segura, N.; Igual-Camacho, C.; Ballester-Gil, Y.Y.; Blasco-Igual, M.C.; Blasco, J.M. The effects of the Pilates training method on balance and falls of older adults: A systematic review and meta-analysis of randomized controlled trials. J. Aging Phys. Act. 2018, 26, 327-344. [CrossRef]

11. Da Silva, A.C.L.G.; Mannrich, G. Pilates na Reabilitação: Uma Revisão Sistemática. Fisioter. Mov. 2009, 22, 449-455. Available online: https:/ / periodicos.pucpr.br/fisio/article/view/19479/18823 (accessed on 27 December 2021).

12. Barrocal, J.; Franco, Y.R.; de Oliveira, N.T.; Moura, K.F.; Cabral, C.M. Aplicação do método Pilates na fisioterapia: Uma revisão sistemática na base de dados PEDro. Fisioter. Bras. 2017, 18, 223-248. [CrossRef]

13. Fleming, K.M.; Herring, M.P. The effects of pilates on mental health outcomes: A meta-analysis of controlled trials. Complement. Ther. Med. 2018, 37, 80-95. [CrossRef] [PubMed]

14. Torales, J.; Almirón, M.; González, I.; Navarro, R.; O’Higgins, M.; Castaldelli-Maia, J.; Ventriglio, A. Mejora el PILATES la salud mental? Mem. Inst. Investig. Cienc. Salud 2019, 17, 97-102. [CrossRef]

15. Goedert, A.; Santos, K.B.; Bento, P.C.; Rodacki, A.L. The effect of Pilates practice on balance in elderly: A systematic review. Rev. Bras. Ativ. Fís. Saúde 2019, 23, 1-7. [CrossRef]

16. Pucci, G.C.; Saavedra, E.B.; Neves, N.F.; Saavedra, J.F. Effect of pilates method on physical fitness related to health in the elderly: A systematic review. Rev. Bras. Med. Esporte 2019, 25, 76-87. [CrossRef]

17. Page, M.J.; Moher, D.; Bossuyt, P.M.; Boutron, I.; Hoffmann, T.C.; Mulrow, C.D.; Shamseer, L.; Tetzlaff, J.M.; Akl, E.A.; Brennan, S.E.; et al. PRISMA 2020 explanation and elaboration: Updated guidance and exemplars for reporting systematic reviews. BMJ 2021, 372, n160. [CrossRef]

18. Page, M.J.; McKenzie, J.E.; Bossuyt, P.M.; Boutron, I.; Hoffmann, T.C.; Mulrow, C.D. PRISMA_2020_flow_diagram_new_SRs_v1. BMJ 2021, 372. Available online: http:/ / www.prisma-statement.org/PRISMAStatement/FlowDiagram (accessed on 27 December 2021).

19. Higgins, J.; Green, S. (Eds.) Cochrane Handbook for Systematic Reviews of Interviews, Version 5.1; The Cochrane Collaboration: Chichester, UK, 2011; Available online: https: / training.cochrane.org/handbook/archive/v5.1/ (accessed on 27 December 2021).

20. Higgins, J.P.; Thomas, J.; Chandler, J.; Cumpston, M.; Li, T.; Page, M.J.; Welch, V.A. (Eds.) Cochrane Handbook for Systematic Reviews of Interventions, 2nd ed.; The Cochrane Collaboration: Chichester, UK, 2019; ISBN 978-1-119-53662-8.

21. Bø, K.; Herbert, R.D. There is not yet strong evidence that exercise regimens other than pelvic floor muscle training can reduce stress urinary incontinence in women: A systematic review. J. Physiother. 2013, 59, 159-168. [CrossRef]

22. Donath, L.; Roth, R.; Hürlimann, C.; Zahner, L.; Faude, O. Pilates vs. balance training in health community-dwelling seniors: A 3-arm, randomized controlled trial. Int. J. Sports Med. 2016, 37, 202-210. [CrossRef]

23. Oliveira, L.C.; Oliveira, R.G.; Pires-Oliveira, D. Comparison between static stretching and the Pilates method on the flexibility of older women. J. Bodyw. Mov. Ther. 2016, 20, 800-806. [CrossRef] 
24. Oliveira, L.C.; Pires-Oliveira, D.A.; Prado, R.C.; Oliveira, D.P.; Antônio, T.D.; Oliveira, R.F.; Oliveira, R.G. Effects of Pilates on postural balance and functional autonomy of elderly: A randomized controlled trial. Man. Ther. Posturology Rehabil. J. 2016, 14, 1-6. [CrossRef]

25. Ángeles, M.A.; Jiménez, J.M.; Sánchez, J.J.G.; Juan, F.R. El efecto de un programa de ejercicios basado en Pilates sobre el estado de ánimo en adultos mayores mexicanos. Retos 2016, 30, 106-109. [CrossRef]

26. Barker, A.L.; Talevski, J.; Bohensky, M.A.; Brand, C.A.; Cameron, P.A.; Morello, R.T. Feasibility of Pilates exercise to decrease falls risk: A pilot randomized controlled trial in community-dwelling older people. Clin. Rehabil. 2016, 30, 984-996. [CrossRef] [PubMed]

27. Filho, M.L.M.; Vianna, J.M.; Venturini, G.R.; de Matos, D.G.; Ferreira, M.E. Avaliacao de diferentes programas de exercicios fisicos na forca muscular e autonomia funcional de idosas. Motricidade 2016, 12, 124-133. Available online: Link.gale.com/apps /doc/A5 00197470 /IFME (accessed on 27 December 2021).

28. Gabizon, H.; Press, Y.; Volkov, I.; Melzer, I. The Effects of Pilates Training on Balance Control and Self-Reported Health Status in Community-Dwelling Older Adults: A Randomized Controlled Trial. J. Aging Phys. Act. 2016, 24, 376-383. [CrossRef] [PubMed]

29. Josephs, S.; Pratt, M.L.; Calk Meadows, E.; Thurmond, S.; Wagner, A. The effectiveness of Pilates on balance and falls in community dwelling older adults. J. Bodyw. Mov. Ther. 2016, 20, 815-823. [CrossRef]

30. Pestana, M.D.; Netto, E.M.; Pestana, M.C.; Pestana, V.S.; Schinoni, M.I. Pilates versus resistance exercise on the serum levels of hs-CRP, in the abdominal circumference and body mass index (BMI) in elderly individuals. Motricidade 2016, 12, 128-140. [CrossRef]

31. Yoon, S.; Kim, J.N.; Lim, H.S. Effects of modified pilates on variability of inter-joint coordination during walking in the elderly. J. Phys. Ther. Sci. 2016, 28, 3463-3467. [CrossRef]

32. Badiei, M.; Shahboulaghi, F.M.; Hosseini, M.A.; Norouzi, M.; Nazari, S. Effect of Pilates exercise on fear of falling in Iranian elderly women. Iran. Rehabil. J. 2017, 15, 389-398. [CrossRef]

33. Teixeira de Carvalho, F.; de Andrade Mesquita, L.S.; Pereira, R.; Neto, O.P.; Amaro Zangaro, R. Pilates and Proprioceptive Neuromuscular Facilitation Methods Induce Similar Strength Gains but Different Neuromuscular Adaptations in Elderly Women. Exp. Aging Res. 2017, 43, 440-452. [CrossRef]

34. Greblo Jurakic, Z.; Krizanic, V.; Sarabon, N.; Markovic, G. Effects of feedback-based balance and core resistance training vs. Pilates training on cognitive functions in older women with mild cognitive impairment: A pilot randomized controlled trial. Aging Clin. Exp. Res. 2017, 29, 1295-1298. [CrossRef] [PubMed]

35. Oliveira, L.C.; Pires-Oliveira, D.A.; Abucarub, A.C.; Oliveira, L.S.; Oliveira, R.G. Pilates increases isokinetic muscular strength of the elbow flexor and extensor muscles of older women: A randomized controlled clinical trial. J. Bodyw. Mov. Ther. 2017, 21, 2-10. [CrossRef] [PubMed]

36. Oliveira, L.C.; Oliveira, R.G.; Pires-Oliveira, D.A. Pilates increases the isokinetic muscular strength of the knee extensors and flexors in elderly women. J. Bodyw. Mov. Ther. 2017, 21, 815-822. [CrossRef] [PubMed]

37. Sofianidis, G.; Dimitriou, A.M.; Hatzitaki, V. A comparative study of the effects of pilates and Latin dance on static and dynamic balance in older adults. J. Aging Phys. Act. 2017, 25, 412-419. [CrossRef] [PubMed]

38. Vieira, N.D.; Testa, D.; Ruas, P.C.; Salvini, T.D.; Catai, A.M.; Melo, R.C. The effects of 12 weeks Pilates-inspired exercise training on functional performance in older women: A randomized clinical trial. J. Bodyw. Mov. Ther. 2016, 21, 251-258. [CrossRef] [PubMed]

39. Alvarenga, G.M.; Charkovski, S.A.; Santos, L.K.; Silva, M.; Tomaz, G.O.; Gamba, H.R. The influence of inspiratory muscle training combined with the Pilates method on lung function in elderly women: A randomized controlled trial. Clinics 2018, 73, 1-5. [CrossRef]

40. Curi, V.S.; Haas, A.N.; Alves-Vilaça, J.; Fernandes, H.M. Effects of 16-weeks of Pilates on functional autonomy and life satisfaction among elderly women. J. Bodyw. Mov. Ther. 2018, 22, 424-429. [CrossRef]

41. Curi, V.S.; Vilaca, J.; Haas, A.N.; Fernandes, H.M. Effects of 16-weeks of Pilates on health perception and sleep quality among elderly women. Arch. Gerontol. Geriatr. 2018, 74, 118-122. [CrossRef]

42. Roller, M.; Kachingwe, A.; Beling, J.; Ickes, D.M.; Cabot, A.; Shrier, G. Pilates Reformer exercises for fall risk reduction in older adults: A randomized controlled trial. J. Bodyw. Mov. Ther. 2018, 22, 983-998. [CrossRef]

43. Tozim, B.M.; Navega, M.T. Effect of pilates method on inspiratory and expiratory muscle strength in the elderly. Rev. Bras. Cineantropometria Hum. 2018, 20, 1-9. [CrossRef]

44. Aibar-Almazán, A.; Martínez-Amat, A.; Cruz-Díaz, D.; de la Torre-Cruz, M.J.; Jiménez-García, J.D.; Zagalaz-Anula, N.; PérezHerrezuelo, I.; Hita-Contreras, F. Effects of Pilates on fall risk factors in community-dwelling elderly women: A randomized, controlled trial. Eur. J. Sport Sci. 2019, 19, 1386-1394. [CrossRef] [PubMed]

45. Liposcki, D.B.; da Silva Nagata, I.F.; Silvano, G.A.; Zanella, K.; Schneider, R.H. Influence of a Pilates exercise program on the quality of life of sedentary elderly people: A randomized clinical trial. J. Bodyw. Mov. Ther. 2019, 23, 390-393. [CrossRef] [PubMed]

46. Buttelli, A.C.; Costa, R.R.; Farinha, J.B.; Fagundes, A.O.; Vieira, A.F.; Barroso, B.M.; Bracht, C.G.; Coconcelli, L.; Reichert, T.; Rocha, V.M.; et al. Pilates training improves aerobic capacity, but not lipid or lipoprotein levels in elderly women with dyslipidemia: A controlled trial. J. Bodyw. Mov. Ther. 2021, 26, 227-232. [CrossRef] [PubMed]

47. Patti, A.; Zangla, D.; Sahin, F.N.; Cataldi, S.; Lavanco, G.; Palma, A.; Fischietti, F. Physical exercise and prevention of falls. Effects of a Pilates training method compared with a general physical activity program: A randomized controlled trial. Medicine 2021, 100, e25289. [CrossRef] 
48. Queiroz, L.C.; Bertolini, S.M.; Bennemann, R.M.; Silva, E.S. The effect Mat Pilates practice on muscle mass in elderly women. Rev. Rede Enferm. Nord. 2016, 17, 618-625. [CrossRef]

49. Roh, S.Y. Effect of a 16-week Pilates exercise program on the ego resiliency and depression in elderly women. J. Exerc. Rehabil. 2016, 12, 494-498. [CrossRef]

50. Roh, S.Y. The effect of 12-week Pilates exercises on wellness in the elderly. J. Exerc. Rehabil. 2016, 12, 119-123. [CrossRef]

51. Hwang, Y.; Park, J.; Lim, K. Effects of pilates exercise on salivary Secretory immunoglobulin a levels in older women. J. Aging Phys. Act. 2016, 24, 399-406. [CrossRef]

52. Bertoli, J.; Biduski, G.M.; de la Rocha Freitas, C. Six weeks of Mat Pilates training are enough to improve functional capacity in elderly women. J. Bodyw. Mov. Ther. 2017, 21, 1003-1008. [CrossRef]

53. Bertoli, J.; Dal Pupo, J.; Vaz, M.A.; Detanico, D.; Biduski, G.M.; de la Rocha Freitas, C. Effects of Mat Pilates on hip and knee isokinetic torque parameters in elderly women. J. Bodyw. Mov. Ther. 2018, 22, 798-804. [CrossRef]

54. Mello, N.F.; Costa, D.L.; Vasconcellos, S.V.; Lensen, C.M.; Corazza, S.T. Método Pilates Contemporâneo na aptidão física, cognição e promoção da qualidade de vida em idosos. Rev. Bras. Geriatr. Gerontol. 2018, 21, 620-626. [CrossRef]

55. Scherf, B.G.; Guadagnin, E.C.; Tier, C.G.; De Almeida Dias, S.L. Effect of a Mat Pilates protocol on fall risk in elderly women. Rev. Andaluza Med. Deport. 2019, 12, 317-321. [CrossRef]

56. Bueno, J.A.; Alves, R.G.; Smoralek, A.C.; Junior, T.S. Haemodynamic and perceptual behaviour in elderly women subjected to one session of different Pilates protocols. Rer. Bras. Pres. Fisio. Exerc. 2019, 13, 481-492. Available online: www.researchgate.net/ publication/335569390_Revista_Brasileira_de_Prescricao_e_Fisiologia_do_Exercicio (accessed on 27 December 2021).

57. Nascimento, M.D.; Pereira, L.G.; Júnior, E.D.; de Castro, H.D.; Appell Coriolano, H.J. Avaliação Da Regulação Exteroceptiva E Interoceptiva Do Equilíbrio Corporal De Idosos Ativos. Rev. Bras. Ciência Mov. 2019, 27, 50-61. [CrossRef]

58. Machado, O.A.; de Campos, S.V.; Killian, L.F.; Machado, G.A.; Gianolla, F. Effect of a single exercise session on blood glucose and blood pressure in elderly. J. Phys. Educ. Sport 2020, 20, 2637-2642. [CrossRef]

59. Choi, W.; Joo, Y.; Lee, S. Pilates exercise focused on ankle movements for improving gait ability in older women. J. Women Aging 2021, 33, 30-40. [CrossRef]

60. Mueller, D.; Redkva, P.E.; Fernando de Borba, E.; Barbosa, S.C.; Krause, M.P.; Gregorio da Silva, S. Effect of mat vs. apparatus pilates training on the functional capacity of elderly women. J. Bodyw. Mov. Ther. 2021, 25, 80-86. [CrossRef]

61. Cruz-Díaz, D.; Bergamin, M.; Gobbo, S.; Martínez-Amat, A.; Hita-Contreras, F. Comparative effects of 12 weeks of equipment based and mat Pilates in patients with chronic low back pain on pain, function and transversus abdominis activation. A randomized controlled trial. Complement. Ther. Med. 2017, 33, 72-77. [CrossRef]

62. Da Luz, M.A.; Costa, L.O.; Fuhro, F.F.; Manzoni, A.C.; Oliveira, N.T.; Cabral, C.M. Effectiveness of mat Pilates or equipment-based Pilates exercises in patients with chronic nonspecific low back pain: A randomized controlled trial. Phys. Ther. 2014, 94, 623-631. [CrossRef]

63. Bueno de Souza, R.O.; Marcon, L.D.; de Arruda, A.S.; Pontes Junior, F.L.; de Melo, R.C. Effects of mat pilates on physical functional performance of older adults: A meta-analysis of randomized controlled trials. Am. J. Phys. Med. Rehabil. 2018, 97, 414-425. [CrossRef] 